CLÁUDIA PESTANA RIBEIRO

Avaliação da virusneutralização cruzada frente BVDV-1 e BVDV-2 no diagnóstico da diarréia viral bovina em animais naturalmente infectados 


\section{Avaliação da virusneutralização cruzada frente BVDV-1 e BVDV-2 no diagnóstico da diarréia viral bovina em animais naturalmente infectados}

Dissertação apresentada ao Programa de PósGraduação em Clínica Veterinária da Faculdade de Medicina Veterinária e Zootecnia da Universidade de São Paulo para obtenção do título de Mestre em Medicina Veterinária

Departamento:

Clínica Médica

Área de concentração:

Clínica Veterinária

Orientadora:

Profa. Dra. Alice Maria Melville Paiva Della Libera

São Paulo 
Autorizo a reprodução parcial ou total desta obra, para fins acadêmicos, desde que citada a fonte.

DADOS INTERNACIONAIS DE CATALOGAÇÃO-NA-PUBLICAÇÃO

(Biblioteca Virginie Buff D’Ápice da Faculdade de Medicina Veterinária e Zootecnia da Universidade de São Paulo)

Ribeiro, Cláudia Pestana

FMVZ

Avaliação da virusneutralização cruzada frente BVDV-1 e

BVDV-2 no diagnóstico da diarréia viral bovina em animais naturalmente infectados / Cláudia Pestana Ribeiro. - São Paulo : C. P. Ribeiro, 2009.

$80 \mathrm{f}$. : il.

Dissertação (mestrado) - Universidade de São Paulo. Faculdade de Medicina Veterinária e Zootecnia. Departamento de Clínica Médica, 2009.

Programa de Pós-Graduação: Clínica Veterinária.

Área de concentração: Clínica Veterinária.

Orientadora: Profa. Dra. Alice Maria Melville Paiva Della Libera.

1. Bovinos. 2. Sorodiagnóstico. 3. Pestivirus. 4. Reação cruzada. 5. Isolados brasileiros. I. Título. 


\section{CERTIFICADO}

Certificamos que o Projeto intitulado "Avaliação da virusneutralização cruzada frente ao BVDV-1 BVDV-2 no diagnóstico da diarréia viral bovina em animais naturalmente infectados", protocolado sob o n'1265/2007, utilizando 1500 (mil) bovinos (amostras), sob a responsabilidade da Profa. Dra. Alice Maria Melville Paiva Della Libera, está de acordo com os princípios éticos de experimentaçâo animal da Comissão de Bioética da Faculdade de Medicina Veterinária e Zootecnia da Universidade de Săo Paulo e foi aprovado na reunião do dia 22 de abril de 2009.

We certify that the Research "Evaluation of the cross-virus neutralization against BVDV-1 and BVDV-2 in the diagnosis of bovine viral diarrhea in naturally infected animals", utilizing 1500 (one hundred) bovines, protocol number $1265 / 2007$, under the responsibility Profa. Dra. Alice Maria Melville Paiva Della Libera, agree with Ethical Principles in Animal Research adopted by Bioethic Commission of the School of Veterinary Medicine and Animal Science of University of Sào Paulo was approved in the meeting of day 04/23/09.

São Paulo, 28 de maio de 2009

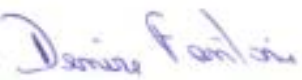

Profa Dra Denise Tabacchi Fantoni Presidente da Comissāo de Bioética FMVZ/USP

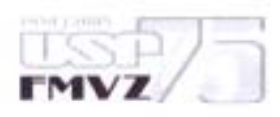

Av. Prof, De. Orlando Maryques de Paiva, n"87 Cidade Usiversitiria "Armando de Salles Oliveira" Sầ Paulo/SP - Brasil 09506-270

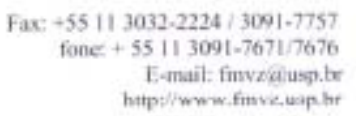


Nome: Ribeiro, Cláudia Pestana

Título: Avaliação da virusneutralização cruzada frente BVDV-1 e BVDV-2 no diagnóstico da diarréia viral bovina em animais naturalmente infectados

Dissertação apresentada ao Programa de Pós-Graduação em Clínica Veterinária da Faculdade de Medicina Veterinária e Zootecnia da Universidade de São Paulo para obtenção do título de Mestre em Medicina Veterinária

Aprovado em:

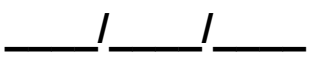

Banca Examinadora

Prof. Dr. Instituição:

Julgamento: Assinatura:

Prof. Dr. Instituição:

Julgamento: Assinatura:

Prof. Dr. Instituição:

Julgamento:

Assinatura: 


\section{DEDICATÓRIA}

Dedico este trabalho aos meus pais, Fernando e Luélia, que com toda dedicação, carinho, paciência e principalmente amor, me deram a oportunidade de ser a pessoa que sou. 


\section{AGRADECIMENTOS}

À Deus, por tudo sempre.

Aos meus pais, as pessoas mais maravilhosas que conheço, me proporcionaram tudo para chegar até aqui. Que Deus os proteja sempre. Amo muito vocês.

À Profa ${ }^{\text {. Dra }}$. Alice Maria Melville Paiva Della Libera, pela confiança, paciência e principalmente amizade. Sinto-me imensamente feliz porque mais do que orientadora, é minha AMIGA.

À Dra. Edviges Maristela Pituco, por todas as oportunidades, desde o primeiro dia, pelo aprendizado diário, convivência que me fizeram uma profissional mais experiente, mas principalmente, uma pessoa melhor.

À Profa. Dra. Maria Claudia Araripe Sucupira, a Macau, pelo apoio, desde a seleção, disciplinas até a confecção da dissertação.

Ao Prof. Wilson Roberto Fernandes, pelas sugestões.

Aos professores doutores do Departamento Carlos Eduardo Larsson, Cássio Xavier de Mendonça Junior, Eduardo Harry Birgel Junior, Enrico Luppi Ortolani, Fernando José Benesi, Lilian Gregory, Márcia Mery Kogika, Maria Helena Akao Larsson, Mitika Kuribayashi Hagiwara, Raquel Yvonne Arantes Baccarin, Silvia Regina Ricci Lucas, Wanderley Pereira de Araújo, Wilson Roberto Fernandes.

Aos pós-graduandos do departamento de Clínica Médica, que colaboraram nas disciplinas e em diversos momentos.

Aos membros da equipe, em especial Maiara Garcia Blagitz, Milton Ricardo Azedo, Fernando Nogueira de Souza, Camila Freitas Batista, Bárbara Gabriela Soares Sanches. Agradeço por me receberem na equipe e por toda ajuda.

À técnica do Laboratório de Imunologia, Claudia Regina Stricagnolo.

À secretária da pós-graduação do departamento, Adelaide, pela ajuda prestada. 
Aos funcionários da biblioteca da FMVZ, Universidade de São Paulo, em especial à Elza Faquim pela seriedade, competência e dedicação.

Ao Instituto Biológico, pesquisadores e funcionários pelas oportunidades.

À Pesquisadora Eliana De Stefano pelo apoio no laboratório, boa vontade e disposição em me ajudar sempre que precisei.

À Pesquisadora Liria Hiromi Okuda, por ser uma profissional exemplar e transmitir seus conhecimentos sempre com alegria e paciência, é muito bom poder trabalhar com você.

À equipe do Laboratório de Viroses de Bovídeos, Nara, Simone, Marília, Monik, Adriana, Leandro, Tia Gel, Washington, Regina, Rosa, que fazem parte do meu crescimento profissional.

À Pesquisadora Dra. Claudia Del Fava, pela ajuda de sempre.

Ao Celso Maruta, pelos esclarecimentos.

Aos meus verdadeiros amigos.

À minha amiga Nádia, que nestes anos de amizade compreendeu os períodos de ausência, e mesmo distante se fez presente.

Ao Ri (Ricardo Spacagna Jordão), por toda ajuda na realização deste e de tantos outros trabalhos, pela compreensão, paciência, principalmente pelo amor e por fazer parte da minha vida. 
"Somos o que repetidamente fazemos. A excelência, portanto, não é um feito, mas um hábito."

Aristóteles

"Pouco importa o julgamento dos outros. Os seres são tão contraditórios que é impossível atender às suas demandas, satisfazê-los. Tenha em mente simplesmente ser autêntico e verdadeiro..."

Dalai Lama 


\section{RESUMO}

RIBEIRO, C. P. Avaliação da virusneutralização cruzada frente BVDV-1 e BVDV-2 no diagnóstico da diarréia viral bovina em animais naturalmente infectados. [Evaluation of the cross virus neutralization against BVDV-1 and BVDV-2 in the diagnosis of bovine viral diarrhea in naturally infected animals]. 2009. $80 \mathrm{f}$. Dissertação (Mestrado em Medicina Veterinária) - Faculdade de Medicina Veterinária e Zootecnia, Universidade de São Paulo, São Paulo, 2009.

A Diarréia Viral Bovina (BVD) provoca grandes perdas econômicas na pecuária mundial, é causada pelo vírus da diarréia viral bovina (BVDV), vírus que apresenta diversidade genética e antigênica entre as estirpes o que provavelmente influencia no diagnóstico. Com a proposta de verificar a presença de anticorpos, sua mensuração e neutralização cruzada frente quatro estirpes do vírus, amostras de 1500 bovinos não vacinados contra BVDV, sendo 519 de 15 rebanhos do Estado de Minas Gerais (MG), 499 de cinco rebanhos do Mato Grosso do Sul (MS) e 482 de cinco rebanhos de São Paulo (SP), foram testadas pela técnica de virusneutralização (VN) com as seguintes estirpes citopatogênicas: BVDV-1 (NADL - estirpe americana e IBSP-11 - isolado nacional) e BVDV-2 (VS-253 - estirpe americana e IBSP-1020 - isolado nacional). Dos 1500 animais, a variação da frequência de sororreagentes ao BVDV foi de $66,07 \%$ a $68,67 \%$, ao analisar os diferentes grupos de animais, de acordo com o estado, a maior frequência de anticorpos foi obtida no MS, seguida por MG e SP, independente da estirpe utilizada na VN. O isolado nacional do genótipo 2, IBSP-1020 foi a estirpe que resultou em maior detecção de reagentes em MG e MS, enquanto que em SP foram as estirpes do genótipo 1. A avaliação dos resultados com as quatro estirpes revelou $73,27 \%(1099 / 1500)$ de animais reagentes a pelo menos um dos vírus, enquanto que, $57,60 \%(864 / 1500)$ foram reagentes aos quatro vírus, simultaneamente, ou seja, estes animais produziram anticorpos que reagiram com todas as estirpes em questão. Os títulos de anticorpos variaram de 10, valor mínimo de detecção da prova, a 5120, sendo que a maior parte dos animais apresentou títulos entre 40 e 160, os títulos observados nos animais de SP foram mais baixos com relação aos animais dos outros estados. A avaliação dos títulos de anticorpos de cada animal, comparando o resultado das estirpes duas a duas, 
revelou diferença na maioria das situações. Conclui-se que, houve alta frequência de ocorrência de bovinos reagentes ao BVDV, que variou de acordo com o sistema de criação e manejo dos rebanhos. Além disso, a utilização de mais de uma estirpe viral, independente do genótipo ou do local de origem do isolado, aumentou a sensibilidade de detecção de animais sororreagentes na VN. Foi evidenciada neutralização cruzada entre todas as estirpes estudadas. Os resultados reforçam a importância de selecionar estirpes representativas das regiões a serem estudadas para inclusão na VN, visando aumentar a sensibilidade do diagnóstico.

Palavras-chave: Bovinos. Sorodiagnóstico. Pestivirus. Reação cruzada. Isolados brasileiros. 


\section{ABSTRACT}

RIBEIRO, C. P. Evaluation of the cross virus neutralization against BVDV-1 and BVDV-2 in the diagnosis of bovine viral diarrhea in naturally infected animals. [Avaliação da virusneutralização cruzada frente BVDV-1 e BVDV-2 no diagnóstico da diarréia viral bovina em animais naturalmente infectados]. 2009. 80 f. Dissertação (Mestrado em Medicina Veterinária) - Faculdade de Medicina Veterinária e Zootecnia, Universidade de São Paulo, São Paulo, 2009.

The bovine viral diarrhea (BVD) causes great economic losses in livestock worldwide, is caused by bovine viral diarrhea virus (BVDV), which presents genetic and antigenic diversity among strains which probably influences the serological diagnosis. For the proposal to verify the presence and titers of antibodies and crossneutralization against four strains of virus, samples from 1,500 bovines naturally infected with BVDV, from the States of Minas Gerais (MG), Mato Grosso do Sul (MS) and São Paulo (SP) were tested by the virus-neutralization test (VN), against four cytopathic strains: BVDV-1 (NADL - American strain and IBSP-11 - Brazilian isolate) and BVDV-2 (VS-253 - American strain and IBSP-1020 - Brazilian isolate). Of the 1,500 animals, the range from $66.07 \%$ to $68.67 \%$, were reactive to BVDV, and the increased frequency of antibodies was obtained in the state of MS, followed by MG and SP, independent of the BVDV strain used in the VN. The national isolate of the genotype 2, IBSP-1020 strain showed highest detection of reagents in MG and MS states, while in SP were the strains of genotype 1. The results with the four strains showed that $73.27 \%(1,099 / 1,500)$ of animals positive to at least one virus, whereas $57.60 \%(864 / 1,500)$ were simultaneously reactive to the four viruses, in other words that is, these animals produced antibodies that cross reacted against all strains in question. The titers of antibodies ranged from 10, the minimum value of detection of VN, to 5120, and that most animals were between 40 and 160 titers. In comparison of antibodies titers among states was observed that animals in SP presented lowest antibody titer that other states. The evaluation of titers of antibodies in each animal, comparing the results of two by two strains showed statistical difference in most situations. It is concluded that there was a high frequency of occurrence of bovine reagents to BVDV, which varied according to the 
system of rasing and management of herds. Moreover, the use of different viral strains, independently of genotype or place of origin of isolate, increased the sensitivity of detection of seropositive animals in the VN. Cross-neutralization was observed among all strains studied. To increase the sensitivity of diagnosis it is important to select for VN the strains representative of the regions to be studied.

Key words: Bovines. Serodiagnosis. Pestivirus. Cross-reaction. Brazilian isolates. 


\section{LISTA DE TABELAS}

Tabela 1 - Número e porcentagem de animais reagentes frente a diferentes estirpes de BVDV, sendo reagentes a pelo menos uma das estirpes utilizadas nas reações de virusneutralização - São Paulo $-2009$.

Tabela 2 - Detecção de animais reagentes simultaneamente frente às estirpes de BVDV utilizadas nas reações de virusneutralização São Paulo - 2009

Tabela 3 - Distribuição dos títulos de anticorpos neutralizantes presentes no soro de 1500 animais frente às estirpes virais (BVDV-1 NADL, BVDV-1 IBSP11, BVDV-2 VS253 e BVDV-2 IBSP1020) - São Paulo - 2009

Tabela 4 - Distribuição dos títulos de anticorpos neutralizantes no soro dos animais do Estado de Minas Gerais frente às quatro estirpes virais - São Paulo - 2009 .

Tabela 5 - Distribuição dos títulos de anticorpos neutralizantes presentes no soro dos animais do Estado de Mato Grosso do Sul (total de 499 animais) frente às quatro estirpes virais - São Paulo 2009.

Tabela 6 - Distribuição dos títulos de anticorpos neutralizantes presentes no soro dos animais do Estado de São Paulo (total de 482 animais) frente às quatro estirpes virais - São Paulo 2009.

Tabela 7 - Comparação dos títulos de anticorpos entre as estirpes, duas a duas, de BVDV dos animais do Estado de Minas Gerais, Mato Grosso do Sul, São Paulo e no total geral - São Paulo 2009. 


\section{LISTA DE GRÁFICOS}

Gráfico 1 - Frequência de bovinos reagentes e não reagentes para o BVDV-1 NADL (estirpe americana) pela virusneutralização São Paulo - 2009 .

Gráfico 2 - Frequência de bovinos reagentes e não reagentes para o BVDV-1 IBSP-11 (isolado nacional) pela virusneutralização São Paulo - 2009

Gráfico 3 - Frequência de bovinos reagentes e não reagentes para o BVDV-2 VS-253 (estirpe americana) pela virusneutralização São Paulo - 2009

Gráfico 4 - Frequência de bovinos reagentes e não reagentes para o BVDV-2 IBSP-1020 (isolado nacional) pela virusneutralização - São Paulo - 2009.

Gráfico 5 - Distribuição dos títulos de anticorpos neutralizantes presentes no soro de 1500 animais frente às estirpes virais (BVDV-1 NADL, BVDV-1 IBSP11, BVDV-2 VS253 e BVDV-2 IBSP1020) - São Paulo - 2009.

Gráfico 6- Distribuição dos títulos de anticorpos neutralizantes no soro dos animais do Estado de Minas Gerais (total de 519 animais) frente às quatro estirpes virais - São Paulo 2009.

Gráfico 7 - Distribuição dos títulos de anticorpos neutralizantes presentes no soro dos animais do Estado de Mato Grosso do Sul (total de 499 animais) frente às quatro estirpes virais -São Paulo 2009.

Gráfico 8 - Distribuição dos títulos de anticorpos neutralizantes presentes no soro dos animais do Estado de São Paulo (total de 482 animais) frente às quatro estirpes virais - São Paulo 2009. 
2 REVISÃO DE LITERATURA.

3 OBJETIVOS.

3.1 OBJETIVOS ESPECÍFICOS

4 MATERIAL E MÉTODOS

4.1 CRITÉRIOS DE INCLUSÃO AMOSTRAL DOS ANIMAIS

4.1.1 Amostras

4.2 CULTIVO CELULAR

4.3 ESTIRPES VIRAIS.

4. 4 CULTIVO VIRAL

4.5 TITULAÇÃO VIRAL

4.6 TESTE DE VIRUSNEUTRALIZAÇÃO.

4.6.1 Soro controle positivo

7 DISCUSSÃO. 
REFERÊNCIAS 


\section{INTRODUÇÃO}

A Diarréia Viral Bovina (BVD - "Bovine Viral Diarrhea") envolve uma variedade de manifestações clínicas (HOUE, 2003), no entanto, a maioria das infecções são inaparentes ou com sintomas discretos (LINDBERG, 2003). A imunodepressão é uma característica da BVD e resulta em infecções secundárias mais severas (BOLIN, 2002). Clinicamente o animal pode apresentar doença respiratória, digestiva, reprodutiva, doença das mucosas e síndrome hemorrágica (BAKER, 1995), embora, os distúrbios reprodutivos sejam os que provocam maiores consequências, inclusive econômicas (GREISER-WILKE; GRUMMER; MOENNING, 2003).

É uma doença mundialmente distribuída, na maioria dos países há alta taxa de animais sororreagentes com idade acima de três anos, variando entre 60 e $90 \%$ (FLORES et al., 2005; HOUE, 1999; KRAMPS et al., 1999; LINDBERG, 2002), promovendo grandes perdas econômicas em países que se dedicam à exploração de rebanhos bovinos (GREISER-WILKE; GRUMMER; MOENNING, 2003; RIDPATH; NEILL; PETERHANS, 2007).

A detecção de anticorpos, através de diferentes testes sorológicos, tem sido usada como indicativo da presença do agente em certas áreas ou populações de bovinos (VIDOR, 1974; HOUE, 1992). A sorologia pode ser considerada um indicativo da dinâmica da infecção e da presença/ausência de animais persistentemente infectados no rebanho (HOUE, 1992).

O agente causador é o vírus da diarréia viral bovina (BVDV - "Bovine Viral Diarrhea Virus"), membro do gênero Pestivirus, família Flaviviridae (FAUQUET et al., 2005), juntamente com o vírus da doença da fronteira dos ovinos (BDV "Border Disease Virus") e o vírus da peste suína clássica (VPSC) (DAHLE; LIESS, 1992; HEINZ et al., 2000; AMES, 2005).

Entre as várias características dos Pestivirus, a mais marcante é o seu elevado grau de variabilidade antigênica, observado especialmente entre amostras do BVDV (BOLIN; RIDPATH, 1996; ROEHE et al., 1998).

As estirpes de BVDV são classificadas em dois genótipos, BVDV-1 e BVDV2 (RIDPATH; BOLIN; DUBOVI, 1994; FULTON et al., 2005) antigenicamente distintos, sobretudo na região da glicoproteína E2 (PELLERIN et al., 1994; VAN 
RIJN et al., 1997), que está envolvida na indução de anticorpos neutralizantes e proteção (DONIS, 1995).

A grande diversidade antigênica observada entre estirpes isoladas do BVDV possui significado especial para epidemiologia, diagnóstico, estratégias de imunização e controle da enfermidade (EDWARDS; PATON, 1995, FULTON et al., 2003a).

Há diversos métodos publicados para detecção de anticorpos séricos (EDWARDS, 1990; HOWARD, 1990; BROCK, 1995; SANDVIK, 1999). A técnica de virusneutralização (VN) é recomendada pela OIE (2008) para a detecção de anticorpos contra BVDV.

A falta de padronização da técnica de VN (diferentes estirpes virais, células e protocolos utilizados) pode dificultar a comparação e interpretação dos resultados de diferentes laboratórios (HAMERS et al., 2002; FLORES et al., 2005). Por ser mais fácil a leitura, a maioria dos laboratórios usa estirpes de BVDV citopatogênicas (cp) para os testes de VN, apesar de técnicas de imuno coloração estarem disponíveis (OIE, 2008). Grande parte dos laboratórios nacionais que realiza o teste de VN para o BVDV utiliza apenas estirpes de BVDV-1 de origem norte americana (Singer e NADL). Nenhuma estirpe sozinha é, provavelmente, ideal para todas as circunstâncias, mas na prática poderia ser selecionada uma estirpe que detecte a maior proporção de reações sorológicas na população bovina local (OIE, 2008). Baixos níveis de anticorpos contra BVDV-2 podem não ser detectados quando se utiliza tipo 1, e vice-versa (FULTON et al., 1997). É importante que o BVDV 1 e 2 sejam usados no teste e não somente um genótipo, pois isso pode levar a um menor número de animais sororreagentes (OIE, 2008).

São restritas as informações relacionadas à imunidade cruzada existente entre os genótipos nos rebanhos do país. A maioria dos trabalhos estuda apenas a correlação existente entre títulos de anticorpos neutralizantes contra BVDV-1 e o BVDV-2 em bovinos vacinados ou experimentalmente infectados (DIAS, 2008). São poucos os estudos que correlacionam bovinos naturalmente infectados com os respectivos títulos de anticorpos neutralizantes. 


\section{REVISÃO DE LITERATURA}

A denominação Diarréia Viral Bovina ("bovine viral diarrhea”, BVD) abrange uma série de manifestações clínico-patológicas causadas pelo vírus da diarréia viral bovina ("bovine viral diarrhea virus", BVDV), considerado um importante patógeno bovinos e responsável por perdas econômicas em rebanhos de todo o mundo (GREISER-WILKE; GRUMMER; MOENNING, 2003; HOUE, 2003). Apesar da manifestação gastroentérica não ser a dominante, foi onde o agente foi inicialmente identificado e por isso a enfermidade denominada BVD (BAKER, 1995).

O primeiro relato de BVD em gado bovino foi realizado por CHILDS em 1946 nos EUA, sendo o vírus descrito pela primeira vez em 1954 (BAKER et al., 1954). Onze anos após a descrição do vírus, ocorreu o primeiro relado de doença gastroentérica, com aspectos clínicos e patológicos compatíveis com a doença das mucosas (DM) (CORREA; NETTO; BARROS, 1968). E o primeiro isolamento do BVDV foi realizado por Vidor (1974), a partir do sangue de feto aparentemente sadio, coletado em matadouro no Rio Grande do Sul.

O BVDV é capaz de infectar uma grande variedade de espécies de ruminantes, tanto domésticos quanto selvagens (LØKEN, 1995; SAUSKER; DYET, 2002; ZUPANCIC et al., 2002; KIM et al., 2006; CHASE et al., 2008).

As manifestações clínicas da infecção podem variar de surtos de diarréia, principalmente em bovinos de seis a 18 meses de idade (DONIS, 1989; BROWNLIE, 1990), até infecções inaparentes (BROWNLIE, 1990). Problemas respiratórios e entéricos são frequentes nas infecções pelo BVDV, porém os distúrbios reprodutivos são os que provocam maiores consequências, diretas e indiretas, nos índices de produção (WOODARD, 1994). Além disso, o BVDV é linfotrófico e a imunossupressão que segue a infecção resulta no aumento da severidade nas infecções secundárias (BOLIN, 2002).

A infecção fetal pode ocorrer após passagem transplacentária do vírus durante a viremia da fêmea, e quando isso ocorre no primeiro trimestre de gestação pode resultar em morte embrionária ou fetal seguida por absorção, mumificação ou aborto (BIELEFELDT OHMANN, 1995). A infecção do feto não imunocompetente (30 a 120 dias de gestação), com estirpes não citopatogênicas 
(ncp), pode resultar em um bezerro persistentemente infectado (PI), caracterizado por imunotolerância específica para a estirpe infectante de BVDV (RIDPATH, 2005). Há hipóteses de que o BVDV ncp iniba funções do sistema imune inato, como a produção de interferon $\alpha / \beta$ e que a imunossupressão esteja relacionada ao desenvolvimento de imunotolerância e infecções persistentes (SCHWEIZERT; PETERHANS, 2001; PETERHANS; JUNGI; SCHWEIZER, 2003).

Os animais PI são a principal fonte de manutenção e transmissão da infecção nos rebanhos, embora pareçam saudáveis, eliminam constantemente o vírus em altos títulos nas secreções e excreções (BOLIN, 1990; BAKER, 1995). Animais PI geralmente sucumbem à doença das mucosas (DM) após superinfecção com o biótipo citopático "homólogo" ao não citopático persistente (BROWNLIE; CLARKE; HOWARD, 1985; HOUE, 1993; BAKER, 1995). A DM, geralmente fatal, ocorre na maioria dos casos entre os seis meses e os dois anos de idade, é caracterizada por diarréia profusa, às vezes sanguinolenta e frequentemente seguida de erosões na mucosa digestiva (BAKER, 1995).

Infecções transplacentárias entre os dias 100 e 150 de gestação podem resultar em malformações congênitas. Nos estádios finais da prenhês, os fetos infectados normalmente são capazes de montar uma resposta imune efetiva, são aparentemente normais no nascimento e têm anticorpos neutralizantes précolostrais anti-BVDV (BROWNLIE; CLARKE; HOWARD, 1989).

Após infecção com BVDV-2 de baixa virulência, os sintomas comumente observados são hipertermia leve, com temperaturas variando de 39,2 a $40,0^{\circ} \mathrm{C}$ por um a três dias, e linfopenia entre 20 e $40 \%$ abaixo dos valores normais (RIDPATH et al., 2000; LIEBER-TENORIO; RIDPATH; NEILL, 2003a). A infecção com BVDV-2 de alta virulência pode apresentar manifestações mais acentuadas, a temperatura corpórea passa de $40,0^{\circ} \mathrm{C}$ e pode alcançar $41,7^{\circ} \mathrm{C}$, por três ou mais dias, linfopenia maior que $40 \%$ e há trombocitopenia maior que 40\% (CORAPI; FRENCH; DUBOVI, 1989; CORAPI et al., 1990; BOLIN; RIDPATH, 1992; LIEBERTENORIO; RIDPATH; NEILL, 2002). A apresentação clínica após infecção experimental com uma estirpe de BVDV-1 foi similar a vista em infecções com BVDV-2 de baixa virulência (CASTRUCCI, et al., 1991).

A transmissão do BVDV pode ocorrer de várias formas, os animais PI são a principal fonte excretando continuamente o vírus, portanto, o contato do animal suscetível com o PI é a forma mais eficiente de propagação da doença (COOK; 
LITTLEJOHNS; JESSEP, 1990; NISKANEN et al., 1996; TREMBLAY, 1996). Bovinos com BVD aguda excretam pequenas quantidade de vírus durante poucos dias (BROWNLIE et al., 1987; TREMBLAY, 1996), podendo infectar outros animais, porém, de maneira menos eficiente (MEYLING; HOUE; JENSEN, 1990). O sêmen de touros PI ou com BVD aguda é uma via de transmissão, sendo que o vírus pode ser liberado mesmo após o final da viremia (KIRKLAND et al., 1991).

Na maioria dos países a BVD é endêmica, com soroprevalência de 60 a 90\% (BROWNLIE, 1990; HOUE, 1999; HULT; LINDBERG, 2005). Nos países livres de febre aftosa é considerado o agente viral mais importante de bovinos e tem sido alvo de numerosos estudos e de programas de controle e/ou erradicação durante décadas (FLORES et al., 2005).

No Brasil, inquéritos soroepidemiológicos revelaram que a infecção está amplamente difundida no rebanho, há vários relatos clínicos e sorológicos demonstrando a presença do vírus (FIGUEIREDO et al., 1997; BOTTON et al., 1998; CANAL et al., 1998; PITUCO; DEL FAVA, 1998; ROEHE et al., 1998; RICHTZENHAIN et al., 1999; NOGUEIRA, 2003; SAMARA; DIAS; MOREIRA, 2004; FLORES et al., 2005; DIAS, 2008). A prevalência da infecção pode ser influenciada pelo sistema de criação e manejo (HOUE, 1999). Regiões com elevadas densidades populacionais apresentam maior prevalência de infecção quando comparadas a regiões com baixas densidades populacionais e rebanhos menores (HOUE; MEYLINE, 1991; LÖKEN; KROGSRUD; LARSEN, 1991).

Dados do Laboratório de Viroses de Bovídeos do Instituto Biológico (LVBIB), obtidos no período de janeiro de 1999 a abril de 2005, em rebanhos leiteiros e de corte de diferentes estados brasileiros, revelaram 50,13\% (8.167/16.291) de animais sororreagentes, por meio da virusneutralização com a estirpe NADL (PITUCO, 2006) $)^{1}$.

Estudos sorológicos utilizando a técnica de VN foram realizados em vários estados brasileiros. Em Minas Gerais, Figueiredo et al. (1997) observaram 61,47\% de amostras reagentes. Em São Paulo, estudo de Pituco e Del Fava (1998) encontrou 40,80\% de sororreagentes e Langoni et al. (1995) observaram 39,5\% de positividade. Na Bahia $14,64 \%$ dos animais estudados por Ribeiro et al. (1987)

\footnotetext{
${ }^{1}$ PITUCO, E. M. São Paulo, 2006 (Relatórios disponíveis no Laboratório de Viroses de Bovídeos Instituto Biológico)
} 
possuíam anticorpos contra BVDV, enquanto Noronha, Campos e Sardi (2003) observaram $56 \%$ de animais reagentes. Em Sergipe a porcentagem encontrada foi de $64,70 \%$ de reagentes (MELO et al., 1997). No Rio Grande do Sul, Krahl et al. (1997) constataram $23,4 \%$ das amostras soropositivas, Vilela et al. (2003), 38,9\% e Quincozes et al. (2007) 66,32\% de positivos. Em Goiás, Brito et al. (2002) observaram $34,5 \%$ de amostras positivas para anticorpos contra BVDV.

Pituco e Del Fava (1998), em estudo realizado com 4.065 animais de vários estados encontraram $47,7 \%$ de reagentes pela reação de VN.

A prevalência de animais $\mathrm{PI}$ nos rebanhos pode variar de 1 a $2 \%$ (BROWNLIE, 1990; HOUE, 1999). No Brasil, Oliveira (1996) realizou triagem em rebanhos com problemas reprodutivos e encontrou $1,2 \%$ de animais PI. Nos Estados Unidos, a frequência de animais PI nos rebanhos varia entre 0,5 e 1,0\% (BROCK, 2003), Fulton et al. (2006) detectaram 0,4\% de PI, enquanto que, Wittum et al. (2001) 0,17\% em bezerros de corte. No Canadá, em 5.129 bezerros estudados menos de 0,1\% eram PI (TAYLOR et al., 1995). Na Alemanha, alguns trabalhos apontam prevalência entre 1 e $2 \%$ de animais PI (FREY; FLEBBE; LIESS, 1996).

O BVDV pertence ao gênero Pestivirus, família Flaviviridae (FAUQUET et al., 2005), juntamente com o vírus da doença da fronteira dos ovinos (BDV "Border Disease Virus") e o vírus da peste suína clássica (VPSC) (DAHLE; LIESS, 1992; HEINZ et al., 2000). É um vírus pequeno medindo 40-60 nm de diâmetro e estrutura icosaédrica, possui RNA de cadeia simples, polaridade positiva, com aproximadamente 12,5 quilobases e envolto por envelope lipoprotéico (FRANCKI et al., 1991; DONIS, 1995; ICTVdB, 2008). Como outros vírus de RNA, o BVDV exibe pronunciada heterogeneidade, expressa em diferenças no fenótipo e genótipo (RIDPATH, 2005).

A replicação do BVDV ocorre no citoplasma celular e o pico máximo de liberação dos vírions ocorre entre 12 e 24 horas após a infecção. Cada célula é capaz de produzir de 100 a 1.000 novos vírions, e as primeiras partículas são liberadas por exocitose 10 horas após a infecção (DENG; BROCK, 1993). O BVDV é facilmente inativado pelo calor, resistindo até uma hora à $56^{\circ} \mathrm{C}$, mas pode manter sua infectividade por 16 meses a $-40^{\circ} \mathrm{C}$. Não é estável no meio ambiente, resistindo apenas por cinco dias, resiste ao $\mathrm{pH}$ entre 5,7 e 9,3, mas a viabilidade máxima é 
alcançada com pH 7,4. Os desinfetantes comuns como os fenóis e clorexidine inativam prontamente o BVDV (MURPHY et al., 1999).

O vírus contém três glicoproteínas: E0, E1 e E2 (FRANCKI et al., 1991; DONIS, 1995; ICTVdB, 2008). As proteínas estruturais exercem funções importantes no revestimento protetor do ácido nucléico viral e permitem a entrada e saída das partículas virais das células infectadas (DONIS, 1995). As glicoproteínas E0 e E2 são responsáveis pela adsorção do vírus a receptores específicos nas células (CORAPI; DONIS; DUBOVI, 1988). Entre as várias características dos Pestivirus, a mais marcante é o seu elevado grau de variabilidade antigênica, observado especialmente entre amostras do BVDV (BOLIN; RIDPATH, 1996; ROEHE et al., 1998). As regiões que refletem maior variabilidade na partícula viral encontram-se nas glicoproteínas do envelope. A diversidade antigênica observada entre estirpes isoladas do BVDV possui significado especial para epidemiologia, diagnóstico e para as estratégias de imunização e controle da enfermidade (EDWARDS; PATON, 1995; FULTON et al., 1997, 2003a).

O BVDV por ser um vírus de RNA de fita simples, tem tendência a altas taxas de mutação, incorporações erradas de nucleotídeos durante a replicação são toleradas contanto que não sejam letais aos vírus. O processo aleatório de acúmulo de mutações nos genes virais ("drift" genético) é responsável pela geração de genótipos e subgenótipos. Enquanto que as diferenças nos biótipos são o resultado das mutações genéticas a partir da recombinação (MEYERS et al., 1991; KUMMERER et al., 2000), vírus citopatogênicos (cp) são idênticos antigenicamente aos vírus não citopatogênicos (ncp) que lhes deram origem (CORAPI; DONIS; DUBOVI, 1988, 1990).

Há dois biótipos de BVDV baseados na presença ou ausência de citopatologia visível em cultivos celulares infectados: cp que provoca vacuolização citoplasmática e morte celular (GILLESPIE; BAKER; McENTEE, 1960) e ncp (CORAPI; DONIS; DUBOVI, 1988; ADLER et al., 1994). A expressão da citopatologia foi correlacionada com a produção da proteína viral NS3 (DONIS; DUBOVI, 1987). Sabe-se que o biótipo ncp é mais predominante na natureza do que o cp (BROWNLIE et al., 1987; RIDPATH, 2005). O cp deriva de mudanças genéticas do ncp (CORAPI; DONIS; DUBOVI, 1988), tais como: inserções, duplicações e/ou rearranjos na região que codifica as proteínas não-estruturais 
NS2-3, que resulta na proteína NS3, exclusiva dos BVDVs citopáticos (DONIS; DUBOVI, 1987; KUMMERER et al., 2000).

A infecção in vitro de células permissivas com BVDV $\mathrm{cp}$ resulta na destruição da estrutura celular, ativação da caspase e indução de apoptose (GRUMMER; BENDFELDT; GREISER-WILKE, 2002; BENDFELDT; GRUMMER; GREISER-WILKE, 2003). Já as infecções in vitro com BVDV ncp resultam no aumento da regulação da proteína Bcl-2 antiapoptótica e supressão da iniciação da morte celular (BENDFELDT; GRUMMER; GREISER-WILKE, 2003). Enquanto a infecção in vitro com BVDV ncp não resulta em morte celular, a depleção de tecidos linfóides é vista nos animais com infecções agudas com estirpes de virulência variada (LIEBER-TENORIO; RIDPATH; NEILL, 2002, 2003a, b, 2004).

Aparentemente, os biótipos têm manifestações diferentes in vivo, as estirpes ncp têm tropismo por leucócitos, órgãos linfóides e trato respiratório, enquanto as estirpes cp são mais frequentemente isoladas de casos de DM (BIELEFELDT OHMANN, 1988; RIDPATH, 2005).

As estirpes de BVDV podem ainda ser separadas em dois genótipos, BVDV1 e BVDV-2 (PELLERIN et al., 1994; RIDPATH; BOLIN; DUBOVI, 1994; FULTON et al., 2005). Segundo Bolin e Ridpath (1996), uma diferença maior que $30 \%$ foi encontrada quando comparadas as sequências do ácido nucléico dos genótipos 1 e 2. Há também uma subclassificação de isolados do BVDV-1 em 11 subgenótipos, de 'a' até 'k' (VILCEK et al., 2001, 2004) e do BVDV-2 em pelo menos dois, 'a' e 'b' (FLORES et al., 2002; PELLERIN et al., 1994; RIDPATH et al., 2000; TAJIMA; DUBOVI, 2005). Há diferenças antigênicas também em estirpes do mesmo genótipo (VOGEL et al., 2002). Enquanto há muitas similaridades entre BVDV-1 e BVDV-2, diferenças biológicas significativas são observadas entre os isolados desses dois genótipos antigenicamente distintos, sobretudo na região da glicoproteína E2, que está envolvida na indução de anticorpos neutralizantes e proteção (PELLERIN et al., 1994; DONIS, 1995; RIDPATH, 2003).

Antes da caracterização do BVDV-2, todas as estirpes descritas na literatura pertenciam ao BVDV-1. O isolamento do tipo 2 a partir de bezerros PI nascidos de vacas vacinadas contendo BVDV-1 sugeriu que havia diferença antigênica entre os vírus de ambos os genótipos (RIDPATH, 2005). A presença de diferenças antigênicas foi confirmada pelos padrões diferentes de ligação com anticorpos monoclonais (RIDPATH; BOLIN; DUBOVI, 1994). 
No Brasil, a caracterização genotípica pioneira de isolados de BVDV foi realizada por Canal et al. (1998), que também demonstraram a presença do BVDV2 no país. A amostra Soldan, isolada de um bezerro com diarréia sanguinolenta em 1991, no Rio Grande do Sul, foi a primeira identificada como BVDV-2. Posteriormente, a análise filogenética de 21 isolados brasileiros revelou que 17 pertenciam ao genótipo BVDV-1 e quatro ao BVDV-2 (GIL, 1998), duas destas amostras foram isoladas de animais com doença gastroentérica e respiratória e as outras de fetos saudáveis em matadouros. Além disso, o anticorpo produzido contra cada uma dessas amostras demonstrou uma baixa reatividade sorológica cruzada frente a amostras de BVDV-1. Um estudo filogenético complementar, pela análise de uma sequência do gene da proteína não-estrutural NS3, revelou que os BVDV-2 brasileiros são geneticamente distintos dos BVDV-2 norte-americanos e europeus, constituindo um subgenótipo a parte, denominado provisoriamente de BVDV-2b (FLORES et al., 2002). Cortez et al. (2005) verificaram 11 isolados brasileiros pertencentes ao BVDV-1, sendo oito do subgenótico 1a e três ao 1b, e seis isolados de BVDV-2, das quais duas de BVDV-2a e quatro de $2 b$.

Análises filogenética e antigênica de isolados brasileiros realizadas por Flores et al. (2000b) revelaram a presença de BVDV-1 e BVDV-2 no rebanho, além de apresentarem uma grande variabilidade antigênica entre eles também são diferentes das estirpes padrão norte americanas e européias (Singer, NADL e Oregon) (BOTTON et al., 1998; FLORES et al., 2002). No Brasil, muitas cepas foram isoladas, mas há carência de informações para melhor caracterização antigênica ou genotípica dos isolados nacionais.

Estudos sobre a resposta imune contra o BVDV em animais imunocompetentes demonstraram que anticorpos contra o vírus podem ser detectados no soro a partir de três semanas após a infecção aguda (HOWARD, 1990; CHASE; CHASE; FAWCETT, 2003). Os níveis de anticorpos aumentam e com aproximadamente 10 a 12 semanas após a infecção, atingem um platô, estes podem ser detectados por pelo menos três anos e, apesar de haver declínio do título após alguns anos (DUFFELL; HARKNESS, 1985; SANDVIK, 1999) permanecerão, provavelmente, presentes por toda a vida do animal (BROWLIE et al., 1987; FREDRIKSEN et al., 1999). Títulos altos de anticorpos neutralizantes previnem o desenvolvimento da doença com vírus homólogo (POTGIETER, 1995; NISKANEN et al., 1996; NOBIRON, et al., 2003). 
Os anticorpos neutralizantes podem ser produzidos para quatro polipeptídeos estruturais do vírus: proteína do capsídeo $(\mathrm{C})$ e glicoproteínas E0, E1 e E2 (BROCK, 1995; DONIS, 1995; CHASE; ELMOWALID; YOUSIF, 2004). Enquanto que, anticorpos não neutralizantes são produzidos contra a proteína nãoestrutural NS2-3 (SANDVIK, 1999). A glicoproteína E2 é a proteína mais imunogênica do BVDV e resulta em altos títulos de anticorpos neutralizantes após infecção (DONIS; CORAPI; DUBOVI, 1988). A indução de imunidade mediada por células por estas proteínas ainda é desconhecida. É difícil e caro mensurar a natureza e qualidade da imunidade ao BVDV nos bovinos (ROEDER; HARKNESS, 1986).

Os animais produzem forte resposta imune para as proteínas NS2-3 e NS3, quando expostos ao vírus em replicação, o valor dessa resposta para proteção imune ainda é desconhecido (BOLIN; RIDPATH, 1989).

Vacinas inativadas proporcionam uma resposta sem a produção de anticorpos contra as proteínas NS2-3 ou NS3, sugerindo que a resposta imune humoral contra essas proteínas estruturais não seja necessária para a proteção (BOLIN; RIDPATH, 1990). Essa imunização resulta em anticorpos contra E2 (BOLIN, 1993), e fornece proteção na forma aguda da doença, mas não livram o rebanho do vírus (BROCK, 2003; GROOMS et al., 2007).

O título de anticorpos neutralizantes necessário para fornecer proteção é desconhecido. (RIDPATH, 2005). Em um estudo, bezerros recém nascidos, negativos para anticorpos contra BVDV receberam diferentes quantidades de colostro para atingirem títulos variados de anticorpos colostrais (BOLIN; RIDPATH, 1995), bezerros com títulos de anticorpos 8 ou menores que 8 apresentaram doença severa após desafio com estirpe virulenta, enquanto que bezerros com títulos entre 16 e 256 não desenvolveram sintomas da doença, mas apresentaram viremia e ocasionalmente leucopenia. A partir destes dados pode-se sugerir que a proteção fetal ocorra em animais com título pelo menos 256 (RIDPATH, 2005).

A natureza da proteção, se humoral ou celular, ainda não é conhecida. No entanto, anticorpos neutralizantes parecem estar envolvidos na proteção a infecções subsequentes (DUBOVI, 1992). A existência de anticorpos neutralizantes em um animal, geralmente é considerada o prognóstico mais significativo de uma resposta imune eficiente (ROBSON; GILLESPIE; BAKER, 1960; BROWN, 1989). 
Estudos demonstraram que uma vaca saudável imunizada com vacina inativada contendo BVDV-1 foi capaz de gerar um bezerro PI, do qual foi isolado BVDV-2 (BOLIN; RIDPATH, 1996). Devido à diversidade antigênica das estirpes virais, vacinas inativadas que induzem anticorpos contra um genótipo podem não proteger contra outro (RIDPATH; BOLIN; DUBOVI, 1994; PATON, 1995), dados sugerem que a imunização de animais com vacinas produzidas com estirpes clássicas do vírus (isolados americanos) podem não conferir proteção adequada contra algumas amostras nacionais (FLORES et al., 2000a; JORDÃO, 2006). Já com o uso de uma vacina contendo BVDV-1 vivo modificado, Cortese et al. (1998b) obtiveram resultados diferentes e concluíram que a vacinação pode proteger bezerros contra a infecção pelo BVDV-2. Bolin e Ridpath (1989) relataram que bezerros imunizados com vacina viva modificada com BVDV-1 produziram anticorpos neutralizantes contra 20 estirpes diferentes de BVDV 21 dias após a vacinação, evidenciando reação cruzada entre as estirpes, e sugerindo que possa haver proteção contra uma ampla variedade de estirpes.

Flores et al. (2000b) revelaram uma variabilidade marcante de amostras brasileiras do BVDV, tanto genética quanto antigênica, com a identificação de vírus dos dois genótipos e subgenótipos, e que algumas amostras brasileiras do vírus da BVD, em especial as amostras do tipo 2, apresentaram reatividade sorológica distinta das estirpes vacinais do tipo 1.

Até o momento, não é conhecido se as estirpes utilizadas na produção de vacinas possuem um espectro antigênico suficientemente amplo para proteger os animais contra as estirpes que ocorrem no campo (PITUCO; DEL FAVA, 1998).

Os primeiros estudos sorológicos da infecção no Brasil datam do início da década de 70 (WIZIGMANN; VIDOR; RICCI, 1971).

A vírusneutalização (VN) é considerada a técnica padrão no diagnóstico sorológico da infecção pelo BVDV por ser sensível e específica, há vários métodos publicados (EDWARDS, 1990; HOWARD, 1990; SANDVIK, 1999; OIE, 2008). É uma técnica laboriosa, demanda estrutura laboratorial com cultivo celular, e maior tempo para a conclusão dos resultados (SANDVIK, 1999).

Trata-se de um ensaio in vitro, em sistema celular, que consiste em incubar o soro do animal com o vírus para possibilitar o bloqueio de estruturas virais por anticorpos específicos, impedindo a interação vírus-receptor celular e cujo resultado é a inibição de efeito citopático padrão (ECP). Diluições seriadas do soro 
e uma concentração previamente estabelecida de vírus são incubadas em condições ideais, determinada quantidade de células deve ser adicionada e incubase novamente. Soro controle padrão positivo e negativo devem ser incluídos em cada teste. Usa-se a inibição da infectividade para detectar anticorpos neutralizantes anti-BVDV, já que os vírus não neutralizados pelos anticorpos infectarão as células induzindo alterações morfológicas (ECP), caso o soro contenha anticorpos específicos contra o vírus utilizado, estes serão neutralizados e as células permanecerão intactas, consequentemente, o ECP não será observado (FULTON et al., 1995).

Por ser mais fácil a interpretação, a maioria dos laboratórios usa estirpes de BVDV cp para os testes de VN, apesar da disponibilidade de técnicas de imuno coloração permitirem a detecção do crescimento ou neutralização de estirpes ncp (OIE, 2008).

É uma técnica altamente específica para cada vírus (OIE, 2008) e pode ser utilizada com a finalidade de identificar a presença de anticorpos neutralizantes específicos, mas também de mensurá-los.

Os anticorpos detectados pela VN são predominantemente contra a glicoproteína E2, que podem resultar em diferentes títulos dependendo da estirpe viral utilizada no teste (DUBOVI, 1992; JONES et al., 2001; COUVREUR et al., 2002).

Não existe estirpe viral padrão que seja ideal em todas as circunstâncias, segundo a OIE (2008) cada região pode selecionar um isolado local capaz de detectar maior número de animais sororreagentes. A ausência de um vírus padrão nacional ou internacional pode explicar a discrepância nos resultados emitidos por diferentes laboratórios para uma mesma amostra (DRISKELL; RIDPATH, 2006).

A escolha da estirpe pode variar entre os laboratórios de diagnóstico, sendo que a maioria utiliza BVDV-1, estirpes Singer ou NADL, além da 'Oregon C24V' ser também amplamente utilizada na VN (FULTON et al., 1997; SANDVIK, 1999; 2005; OIE, 2008).

Devido à especificidade da VN, baixos níveis de anticorpos contra BVDV-2 podem não ser detectados quando BVDV-1 é utilizado na VN, e vice-versa (FULTON et al., 1997). Segundo OIE (2008) seria importante que ambos fossem utilizados nos testes, visto que a avaliação com apenas um genótipo pode levar a detecção de número mais baixo de animais reagentes. Alguns autores sugeriram a 
inclusão de isolados locais dos dois genótipos nos testes de VN (FLORES et al., 2000a). Pellerin et al. (1994) também observaram baixa reatividade sorológica entre BVDV-1 e BVDV-2.

Sabe-se que há reatividade cruzada entre BVDV-1 e BVDV-2, entretanto, quando os vírus são do mesmo genótipo os títulos de anticorpos são mais altos do que entre vírus de diferentes genótipos (MAKOSCHEY et al., 2001; FULTON et al., 2003a, b; HAMERS et al., 2003).

Os títulos neutralizantes cruzados são tipicamente um log ou maiores dentro do mesmo genótipo (FULTON et al., 2003a). Bovinos suscetíveis responderam com títulos de anticorpos neutralizantes mais altos contra o genótipo do BVDV com o qual entraram em contato comparado aos títulos mais baixos contra outros BVDVs (JONES, et al., 2001; COUVREUR et al., 2002; SCHIRRMEIER, et al., 2004). Entretanto, a variação de animal para animal e a divergência entre os subgenótipos podem dificultar a diferenciação dos BVDVs com base somente na sorologia (MULLER et al., 1997; BOLIN; RIDPATH, 1998).

Estudos de neutralização cruzada em bovinos vacinados com vacina viva modificada ou inativada (CORTESE et al., 1998c; HAMERS et al., 2002) demonstraram ampla neutralização cruzada. Entretanto, estudos de campo não mostraram esta extensa neutralização cruzada (JONES et al., 2001; FULTON et al., 2003a).

Estudos de neutralização cruzada in vitro mostram essa diversidade antigênica e alertam para as suas possíveis implicações para o diagnóstico e proteção vacinal (EDWARDS; PATON, 1995; VAN OIRSCHOT; BRUSCHKE; VAN RIJN, 1999; FULTON et al., 2003a).

Diversos autores observaram diversidade antigênica entre as estirpes de BVDV (BOLIN, RIDPATH, 1989; RIDPATH; BOLIN; DUBOVI, 1994; REDDY et al., 1995; RIDPATH, 2005), e alguns isolados demonstraram baixa reatividade sorológica cruzada entre as estirpes vacinais norte-americanas Singer, NADL e Oregon (BOTTON et al., 1998). Outro estudo observou, com o uso da VN, uma diferença nos títulos de anticorpos neutralizantes dependendo do genótipo utilizado como desafio (FULTON et al., 1997). Os genótipos do BVDV também demonstraram diferenças antigênicas em estudos de neutralização cruzada (CORTESE et al., 1998a; ELLIS et al., 2001; MAKOSCHEY et al., 2001; FULTON et al., 2003a, b; HAMERS et al., 2003). 
Enquanto 11 subgenótipos de BVDV-1 e dois subgenótipos propostos para o BVDV-2 podem ser diferenciados pela análise filogenética, não há diferenciação por meios antigênicos (VILCEK et al., 2001; FLORES et al., 2002). Biologicamente, as diferenças significantes nos determinantes antigênicos entre os subgenótipos do BVDV-1 foram sugeridas em várias linhas de evidência incluindo a comparação de títulos de anticorpos (FULTON et al., 2003a, b). Apenas com relação ao aspecto antigênico, não se pode apontar diferenças entre os subgenótipos do BVDV (RIDPATH; NEILL; PETERHANS, 2007).

Considerando a carência de dados sobre a diferença entre as estirpes de BVDV comumente usadas nos testes diagnósticos, questões sobre a utilização de ambos os genótipos e isolados regionais na reação de VN devem ser esclarecidas.

A detecção dos anticorpos neutralizantes contra BVDV tem aplicações que incluem a avaliação nos mecanismos de defesa de bovinos bem como a mensuração da resposta humoral de animais vacinados.

A reatividade sorológica e proteção cruzada entre BVDV-1 e BVDV-2 e entre isolados locais é baixa devido a grande variabilidade antigênica do BVDV (PELLEGRIN et al., 1997; EDWARDS, PATON, 1995; BOTTON et al., 1998).

Há interesse em saber se os diagnósticos disponíveis detectam BVDV-1 e BVDV-2 e se há diferenças entre estas estirpes comumente utilizadas em diagnóstico e entre isolados regionais, como os brasileiros (BVDV-1 IBSP-11 e o BVDV-2 IBSP-1020).

Este trabalho se propôs a estudar a neutralização cruzada dos anticorpos de bovinos naturalmente infectados com o vírus da BVD frente quatro estirpes virais. 


\section{OBJETIVOS}

Analisar a resposta imune humoral de bovinos naturalmente infectados com o vírus da BVD, pela mensuração de anticorpos neutralizantes e avaliar a neutralização cruzada frente quatro estirpes citopatogênicas (BVDV-1 NADL, BVDV-1 IBSP-11, BVDV-2 VS-253 e BVDV-2 IBSP-1020) pela técnica de virusneutralização.

\subsection{OBJETIVOS ESPECÍFICOS}

a. Mensurar os anticorpos séricos de bovinos naturalmente infectados utilizando a reação de virusneutralização (VN) com quatro estirpes virais citopatogênicas (BVDV-1 NADL, BVDV-1 IBSP-11, BVDV-2 VS-253 e BVDV-2 IBSP-1020).

b. Analisar a neutralização cruzada dos anticorpos frente as quatro estirpes virais utilizando a reação de virusneutralização. 


\section{MATERIAL E MÉTODOS}

A seleção dos animais, obtenção das amostras e técnicas de cultivos celular e viral, titulação viral e virusneutralização, são descritas neste capítulo.

\subsection{CRITÉRIOS DE INCLUSÃO AMOSTRAL DOS ANIMAIS}

Foram utilizados 1500 bovinos de ambos os sexos, com idade entre 24 a 36 meses, não vacinados contra BVDV, sem sintomas clínicos, procedentes de rebanhos localizados nos Estados de Minas Gerais (MG), Mato Grosso do Sul (MS) e São Paulo (SP), atendidos pela rotina diagnóstica do Laboratório de Viroses de Bovídeos do Instituto Biológico (LBV-IB) no período de 2004 a 2006.

Foram estudados 519 bovinos, raça Girolando, de 15 rebanhos do Triângulo Mineiro, criados em sistema intensivo ou semi-intensivo. Em cinco rebanhos da região sudoeste do Mato Grosso do Sul, 499 animais da raça Nelore, criados em sistema extensivo. E, 482 bovinos, da raça Holandesa, pertencente a cinco rebanhos localizados na região noroeste do estado de São Paulo, criados em sistema intensivo ou semi-intensivo.

O presente estudo foi realizado com a parceria do LVB-IB com o Laboratório de Imunodiagnóstico (VCM FMVZ-USP) e com a Clínica de Bovinos e Pequenos Ruminantes do HOVET FMVZ-USP.

Todos os procedimentos foram realizados de acordo com os princípios éticos de experimentação animal adotados pelo Colégio Brasileiro de Experimentação Animal (COBEA), o trabalho foi aprovado pela Comissão de Bioética da Faculdade de Medicina Veterinária e Zootecnia da Universidade de São Paulo (Protocolo no 1265/2007). 


\subsubsection{Amostras}

Foi coletada amostra de sangue de cada animal, por punção da veia jugular externa, utilizando-se o sistema a vácuo em tubo siliconizado sem anticoagulante, com capacidade de $10 \mathrm{~mL}$. A amostra identificada foi transportada sob refrigeração até o LVB-IB.

Após a coagulação do sangue as amostras foram centrifugadas a $600 \times \mathrm{g}$ por 15 minutos, o soro obtido foi incubado a $56^{\circ} \mathrm{C}$ por 30 minutos, a fim de inativar a cascata de complemento, e armazenado a $-20^{\circ} \mathrm{C}$ até o momento do uso.

\subsection{CULTIVO CELULAR}

Os procedimentos de cultivo, titulação viral e testes de virusneutralização, foram realizados em linhagem celular de epitélio renal bovino "Madin-Darby Bovine Kidney" (MDBK) CCL-22, proveniente da "American Type Culture Collection" (ATCC) Manassas, EUA, livre de Pestivirus. As células foram armazenadas em nitrogênio líquido no LVB-IB. Conforme recomendado pelo "Manual of Diagnostic Tests and Vaccines for Terrestrial Animals, World Organization for Animal Health Office International des Epizooties" (OIE, 2008) as células foram utilizadas por no máximo 20 passagens.

As células foram cultivadas em Meio Essencial Mínimo (MEM - Cultilab, Campinas, Brasil), acrescido de 0,2\% de bicarbonato de sódio (Merck, Darmstadt, Alemanha), tamponado com $25 \mathrm{mM}$ de ácido 4-(2-hidroxietil)-1piperazineetanossulfônico (HEPES - Biosolve, Westford, EUA) e suplementado com $5 \%$ de soro fetal bovino livre de anticorpos contra BVDV (SFB - Cultilab, Campinas, Brasil). Para a manutenção, as células foram cultivadas em frascos de poliestireno, com $150 \mathrm{~cm}^{2}$ de área (Corning, New York, EUA) e mantidas em estufa a temperatura de $37^{\circ} \mathrm{C}$.

Os subcultivos foram realizados a cada 72 horas, utilizando uma solução Tripsina-Versene (Sigma-Aldrich, Steinheim, Alemanha) para a desagregação das células. $\mathrm{O}$ inóculo celular foi constituído de $2 \times 10^{5}$ células $/ \mathrm{mL}$ e a contagem feita 
em câmara de Neubauer (Optik Labor, Friedrichshofen, Alemanha). As células e o SFB foram controlados periodicamente para presença de Pestivirus por reação de Imunoperoxidase Direta, ELISA Antígeno (IDEXX, Westbrook, EUA) e Transcrição Reversa combinada à Reação em Cadeia pela Polimerase (RT-PCR).

\subsection{ESTIRPES VIRAIS}

Foram utilizadas as seguintes estirpes virais citopatogênicas:

- BVDV-1 NADL isolado no "National Animal Disease Laboratory" na década de 50 nos EUA e adquirido na "American Type Culture Collection" (VR-1422, ATCC);

- BVDV-1 IBSP-11 isolado no LVB-IB de um caso clínico de São Paulo na década de 90, gentilmente cedido pela Dra. Edviges Maristela Pituco (LVBIB);

- BVDV-2 VS-253 isolado da década de 90, gentilmente cedido pelo Dr. Eduardo Flores, originado da "University of Nebraska at Lincoln", EUA, Dr. Rubens Donis;

- BVDV-2 IBSP-1020 isolado de um caso clínico de São Paulo, no LVB-IB em 2002, gentilmente cedido pela Dra. Edviges Maristela Pituco (LVB-IB).

\subsection{CULTIVO VIRAL}

Para a replicação dos vírus, as garrafas com 24 horas de monocamada celular pré-formada foram infectadas com títulos mínimos (BVDV-1 NADL 10,5, BVDV-1 IBSP-11 106,3, BVDV-2 VS-253 10,5 e BVDV-2 IBSP-1020 10 ${ }^{5,3}$ DICT $_{50} / \mathrm{mL}$ - doses infectantes para $50 \%$ dos cultivos de tecido por $\mathrm{mL}$ ), acrescidas de $70 \mathrm{~mL}$ de MEM com 5\% de SFB e 1\% de antibióticos: Penicilina G Potássica 11.200 $\mathrm{UI} / \mathrm{mL}$; Estreptomicina 0,01 g/mL; Gentamicina 0,01 g/mL; L-Glutamina 0,029 g/mL e Anfotericina B 0,5 mg/mL (Cultilab, Campinas, Brasil) e permaneceram a $37^{\circ} \mathrm{C} . \mathrm{O}$ cultivo foi observado diariamente e após $90 \%$ de destruição da monocamada 
celular, a suspensão viral foi recolhida, centrifugada a 600 x g, por 15 minutos a $+4^{\circ} \mathrm{C}$ (IEC, International Centrifuge, modelo PR-2, Needham, EUA) e as alíquotas feitas em tubos de criogenia (TPP, Techno Plastic Products AG, Switzerland) que foram armazenadas em ultrafreezer (Thermo Electron Corporation, Waltham, EUA) a $-86^{\circ} \mathrm{C}$ e nitrogênio líquido $-196^{\circ} \mathrm{C}$ até o momento do uso.

\subsection{TITULAÇÃO VIRAL}

As estirpes foram tituladas em placas de microtitulação de poliestireno, de fundo chato com 96 cavidades (Corning, New York, EUA), em diluições seriadas na base $10\left(10^{-1}\right.$ a $\left.10^{-9}\right)$, sendo diluídas em meio MEM com $1 \%$ de antibióticos, $50 \mu \mathrm{L}$ por cavidade, em oito repetições. As duas últimas colunas foram utilizadas como controle de células, não recebendo inóculo viral. Imediatamente em seguida, $50 \mu \mathrm{L}$ de uma suspensão de $3 \times 10^{5}$ células $/ \mathrm{mL}$, preparada em meio MEM contendo $5 \%$ de SFB, foi adicionada em cada uma das cavidades. As placas foram incubadas em estufa $37^{\circ} \mathrm{C}$ com $5 \%$ de $\mathrm{CO}_{2}$ e umidade controlada (Thermo Electron Corporation, Waltham, EUA) por quatro dias. A leitura foi realizada em microscópio invertido. O título viral foi calculado utilizando-se o método de Reed e Muench (1938).

\subsection{TESTE DE VIRUSNEUTRALIZAÇÃO}

O teste de virusneutralização (VN), descrito no "Manual of Diagnostic Tests and Vaccines for Terrestrial Animals, World Organisation for Animal Health" (OIE, 2008), foi utilizado para mensurar os anticorpos neutralizantes presentes no soro dos bovinos estudados, frente às diferentes estirpes.

Foram utilizadas placas de microtitulação com 96 cavidades de fundo chato. A coluna um da placa teste foi destinada para o controle de células, a coluna dois para controle da toxicidade de cada soro e nas colunas três até 12, as amostras foram diluídas em série, na base logarítmica 2, a partir da diluição 1:10 até 1:5120, 
utilizando-se meio MEM. Para validação da prova foi incluído um "pool" de soros como controle negativo e positivo com títulos de anticorpos conhecidos. Feita a diluição das amostras, foi adicionada à placa 200 DICT $_{50}$ do vírus, exceto no controle de células e de soro.

$\mathrm{Na}$ placa controle, nas colunas um a quatro receberam o controle de $\mathrm{DICT}_{50}$ $\left(0,2 ; 2 ; 20\right.$ e 200 DICT $\left._{50} / \mathrm{mL}\right)$, nas colunas cinco até oito, foi feita a retrotitulação do mesmo vírus utilizado na diluição das doses infectantes. E as colunas 11 e 12 serviram como controle negativo, recebendo somente meio MEM.

As placas foram incubadas por uma hora em estufa $37^{\circ} \mathrm{C}$ com $5 \%$ de $\mathrm{CO}_{2}$, após esse período receberam $50 \mu \mathrm{L}$ de suspensão de células MDBK na concentração de $3 \times 10^{5}$ células $/ \mathrm{mL}$, em cada cavidade. A infectividade foi indicada pelo efeito citopático visível na monocamada celular em placas, em microscópio invertido, após quatro dias de incubação a $+37^{\circ} \mathrm{C}$ e $5 \%$ de $\mathrm{CO}_{2}$. O título de anticorpos foi expresso como a maior diluição do soro que inibiu completamente a infectividade em ambas as cavidades de cada diluição, sendo a menor diluição detectada pela prova 1:10, meio MEM foi utilizado como diluente. Tendo em vista que os soros foram analisados em duplicata, os títulos de anticorpos foram expressos como o inverso da diluição que inibiu o aparecimento de ECP nas duas repetições e foram consideradas reagentes as amostras com título igual ou superior a 10. O teste foi validado utilizando controle de células, controle de soros, do resultado dos soros controle e da retrotitulação, pelo método de Reed e Muench (1938).

\subsubsection{Soro controle positivo}

As amostras de soro controle positivo para BVDV-1 NADL, BVDV-1 IBSP-11, BVDV-2 VS-253 e BVDV-2 IBSP-1020 foram obtidas no LVB-IB, provenientes de animais cujo soro foi testado pela VN frente à estirpe homóloga. 


\section{ANÁLISE ESTATÍSTICA}

Para a análise estatística foi utilizado o programa SPSS (SPSS Inc., Chicago, Estados Unidos, versão 16.0).

Os dados obtidos foram analisados quanto a sua distribuição paramétrica ou não pela prova de Kolmogorov-Smirnov. Os dados que apresentaram distribuição não paramétrica e foram comparados pelo teste de Mann-Whitney. E a medida de correlação não paramétrica entre os resultados positivos foi analisada pelo teste McNermar (THRUSFIELD, 2004).

A comparação dos títulos de anticorpos neutralizantes, de cada animal, contra os BVDVs foi realizada pelo Teste de Wilcoxon, com intervalo de confiança de $95 \%$, por serem quatro variáveis (estirpes), foi feita a correção de Bonferroni. 


\section{RESULTADOS}

A análise para a presença de anticorpos séricos em 1500 bovinos contra quatro estirpes do vírus da BVD revelou que, para BVDV-1 NADL 66,09\% (343/519) dos animais foram reagentes em Minas Gerais, 91,98\% (459/499) no Mato Grosso do Sul e 39,21\% (189/482) em São Paulo. A frequência de NADL encontrada no total de animais foi de 66,07\% (991/1500) (Gráfico 1).

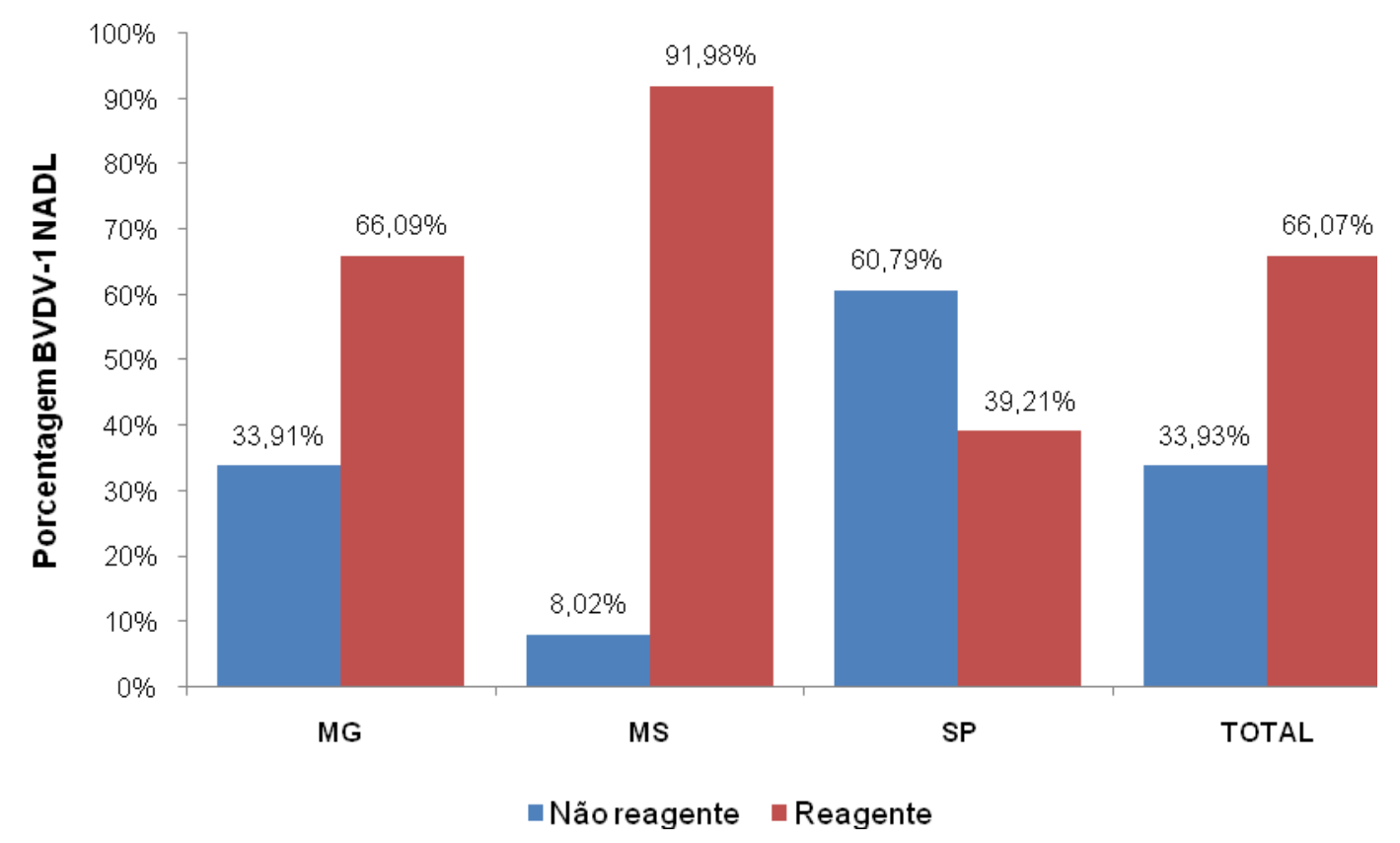

Gráfico 1 - Frequência de bovinos reagentes e não reagentes para o BVDV-1 NADL (estirpe americana) pela virusneutralização - São Paulo - 2009.

Quando o vírus BVDV-1 IBSP-11 foi utilizado na VN, 67,40\% (350/519) dos animais foram reagentes em MG, 92,99\% (464/499) no MS, 39,21\% (189/482) em SP e 66,87\% (1003/1500) no total de animais (Gráfico 2). A proporção de reagentes frente BVDV VS-253 foi de 68,40\% (355/519) em MG, 92,18\% (460/499) no MS, 36,93\% (178/482) em 66,20\% (993/1500) no total de animais (Gráfico 3). 


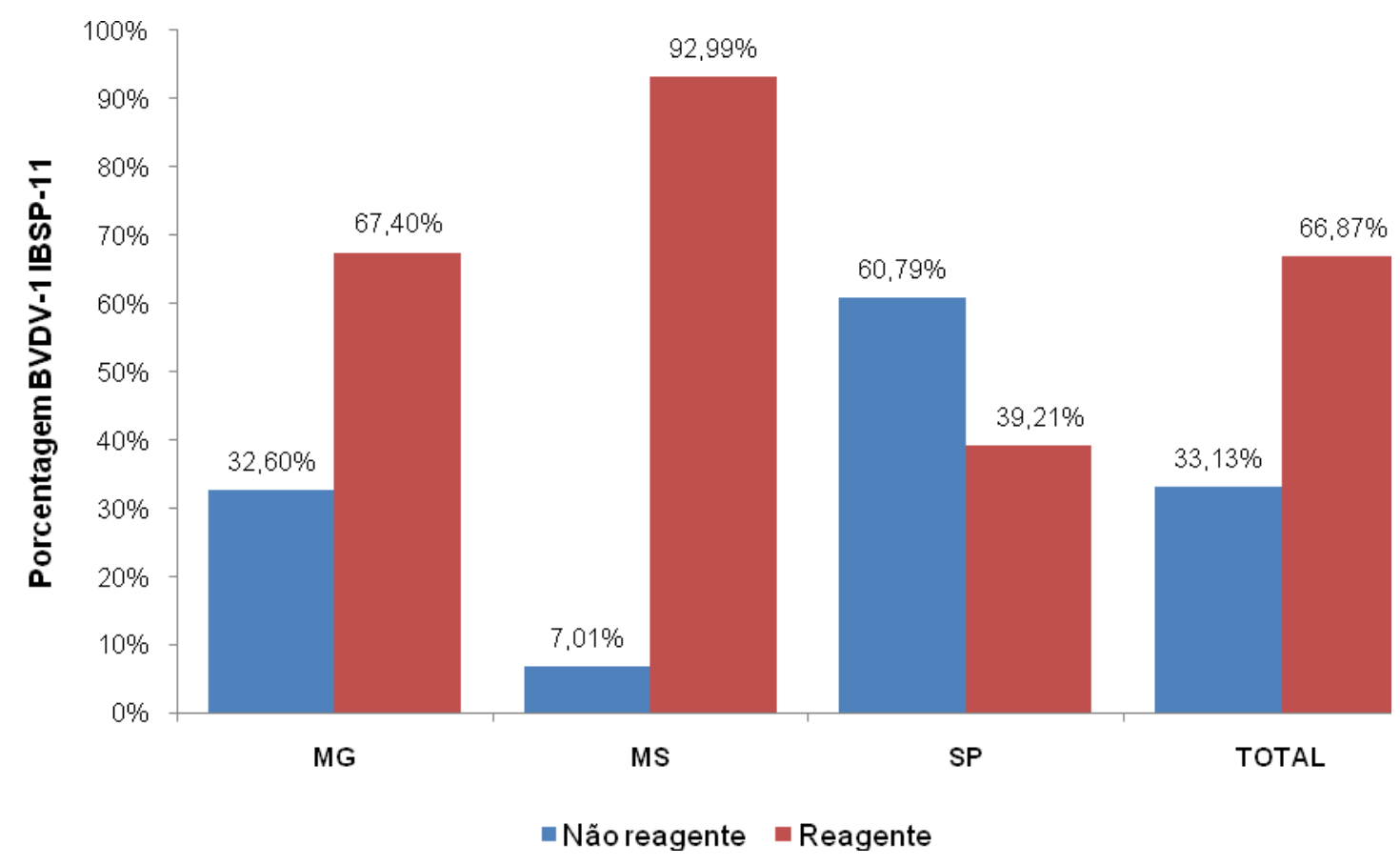

Gráfico 2 - Frequência de bovinos reagentes e não reagentes para o BVDV-1 IBSP-11 (isolado nacional) pela virusneutralização - São Paulo - 2009.

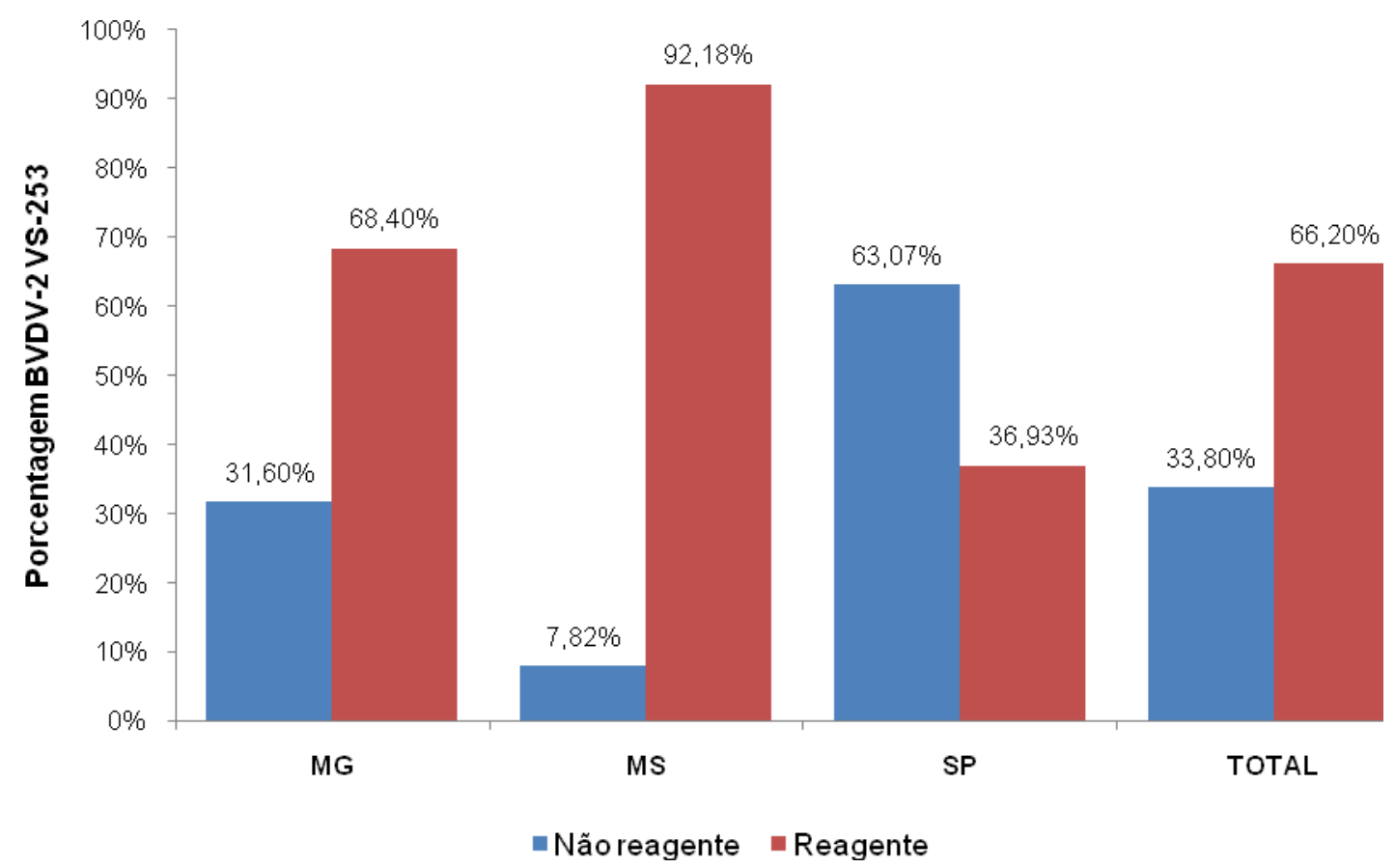

Gráfico 3 - Frequência de bovinos reagentes e não reagentes para o BVDV-2 VS-253 (estirpe americana) pela virusneutralização - São Paulo - 2009. 
E a porcentagem de sororreagentes ao BVDV-2 IBSP-1020 foi $68,60 \%$ (356/519) em MG, 97,39\% (486/499) no MS, 39,00\% (188/482) em SP e 68,67\% (1030/1500) no total de animais (Gráfico 4).

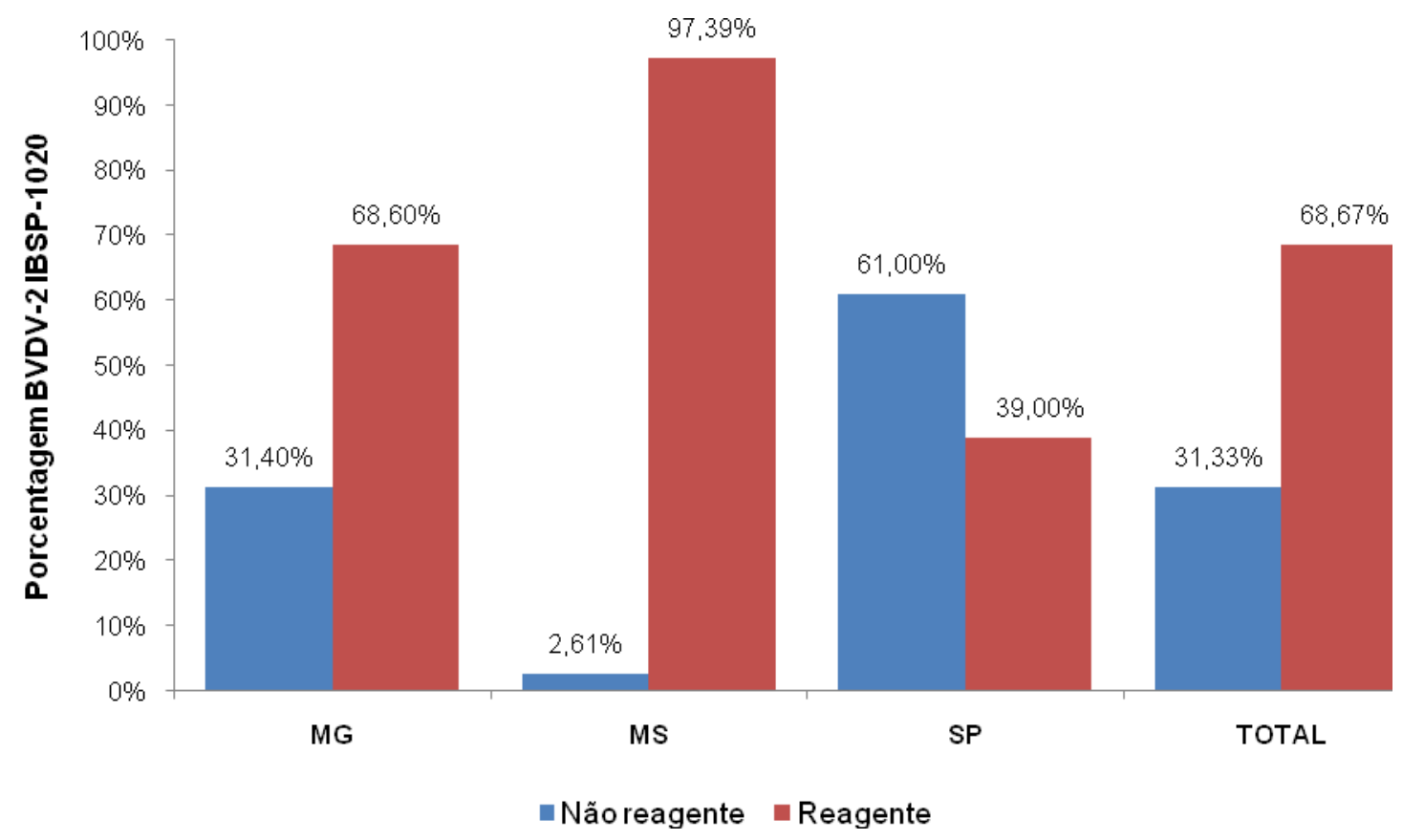

Gráfico 4 - Frequência de bovinos reagentes e não reagentes para o BVDV-2 IBSP-1020 (isolado nacional) pela virusneutralização - São Paulo - 2009.

Com base nos resultados apresentados na tabela 1, pode-se avaliar a diferença entre os vírus utilizados para o diagnóstico. Os módulos foram divididos de acordo com a quantidade de estirpes, ou seja, referem-se ao número de animais reagentes a pelo menos uma das estirpes em questão. Para um melhor entendimento a análise destes resultados foi dividida de acordo com a origem dos animais e para cada módulo. 
Tabela 1 - Número e porcentagem de animais reagentes frente a diferentes estirpes de BVDV, sendo reagentes a pelo menos uma das estirpes utilizadas nas reações de virusneutralização São Paulo - 2009.

\begin{tabular}{|c|c|c|c|c|c|c|c|c|c|}
\hline \multicolumn{2}{|c|}{$\begin{array}{l}\text { Módulo e } \\
\text { quantidade } \\
\text { de estirpes }\end{array}$} & \multicolumn{2}{|c|}{$\begin{array}{l}\text { Estirpes de } \\
\text { BVDV-1 }\end{array}$} & \multicolumn{2}{|c|}{$\begin{array}{l}\text { Estirpes de } \\
\text { BVDV-2 }\end{array}$} & MG & MS & SP & TOTAL \\
\hline \multirow{4}{*}{$\begin{array}{l}\bar{o} \\
\stackrel{1}{5} \\
\stackrel{0}{\Sigma}\end{array}$} & \multirow{4}{*}{ 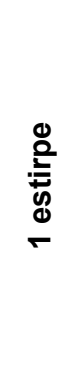 } & \multirow[t]{4}{*}{ NADL } & & & & $\begin{array}{c}343^{\mathrm{aCE} E^{\star}} \\
(66,09 \%)^{\star *}\end{array}$ & $\begin{array}{c}459^{\mathrm{aA}} \\
(91,98 \%)\end{array}$ & $\begin{array}{c}189^{\mathrm{aAC}} \\
(39,21 \%)\end{array}$ & $\begin{array}{c}991^{\mathrm{aA}} \\
(66,07 \%)\end{array}$ \\
\hline & & & $\begin{array}{c}\text { IBSP- } \\
11\end{array}$ & & & $\begin{array}{c}350^{\mathrm{abDE}} \\
(67,40 \%)\end{array}$ & $\begin{array}{c}464^{\mathrm{aA}} \\
(92,99 \%)\end{array}$ & $\begin{array}{c}189^{\mathrm{aAC}} \\
(39,21 \%)\end{array}$ & $\begin{array}{c}1003^{\mathrm{aA}} \\
(66,87 \%)\end{array}$ \\
\hline & & & & $\begin{array}{l}\text { VS- } \\
253\end{array}$ & & $\begin{array}{c}355^{\mathrm{bADK}} \\
(68,40 \%)\end{array}$ & $\begin{array}{c}460^{\mathrm{aA}} \\
(92,18 \%)\end{array}$ & $\begin{array}{c}178^{\mathrm{aA}} \\
(36,93 \%)\end{array}$ & $\begin{array}{c}993^{\mathrm{aA}} \\
(66,20 \%)\end{array}$ \\
\hline & & & & & $\begin{array}{c}\text { IBSP- } \\
1020\end{array}$ & $\begin{array}{c}357^{\mathrm{abACDFK}} \\
(68,79 \%)\end{array}$ & $\begin{array}{c}486^{\mathrm{bCD}} \\
(97,39 \%)\end{array}$ & $\begin{array}{c}188^{\mathrm{aA}} \\
(39,00 \%)\end{array}$ & $\begin{array}{c}1030^{\mathrm{bC}} \\
(68,67 \%)\end{array}$ \\
\hline \multirow{6}{*}{ 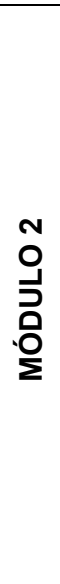 } & \multirow{6}{*}{ 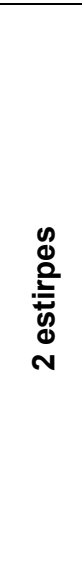 } & NADL & $\begin{array}{c}\text { IBSP- } \\
11\end{array}$ & & & $\begin{array}{l}360^{\mathrm{abAHRT}} \\
(69,36 \%)\end{array}$ & $\begin{array}{c}489^{\text {bCCE }} \\
(98,00 \%)\end{array}$ & $\begin{array}{l}223^{\mathrm{aDFKL}} \\
(46,27 \%)\end{array}$ & $\begin{array}{c}1070^{\mathrm{aDE}} \\
(71,33 \%)\end{array}$ \\
\hline & & NADL & & $\begin{array}{l}\text { VS- } \\
253\end{array}$ & & $\begin{array}{c}362^{\mathrm{abFHIQS}} \\
(69,75 \%)\end{array}$ & $\begin{array}{c}490^{\mathrm{bcCF}} \\
(98,20 \%)\end{array}$ & $\begin{array}{l}207^{\text {cdEGHI }} \\
(42,95 \%)\end{array}$ & $\begin{array}{c}1059^{\mathrm{aD}} \\
(70,60 \%)\end{array}$ \\
\hline & & NADL & & & $\begin{array}{l}\text { IBSP- } \\
1020\end{array}$ & $\begin{array}{c}371^{\text {CBJO }} \\
(71,48 \%)\end{array}$ & $\begin{array}{c}497^{\mathrm{aB}} \\
(99,60 \%)\end{array}$ & $\begin{array}{l}219^{\mathrm{abFJK}} \\
(45,44 \%)\end{array}$ & $\begin{array}{c}1087^{\mathrm{bFH}} \\
(72,47 \%)\end{array}$ \\
\hline & & & $\begin{array}{c}\text { IBSP- } \\
11\end{array}$ & $\begin{array}{l}\text { VS- } \\
253\end{array}$ & & $\begin{array}{l}359^{\mathrm{aAIKN}} \\
(69,17 \%)\end{array}$ & $\begin{array}{c}494^{\mathrm{bBDF}} \\
(99,00 \%)\end{array}$ & $\begin{array}{l}208^{\text {bcGHJ }} \\
(43,15 \%)\end{array}$ & $\begin{array}{c}1061^{\mathrm{aD}} \\
(70,73 \%)\end{array}$ \\
\hline & & & $\begin{array}{c}\text { IBSP- } \\
11\end{array}$ & & $\begin{array}{l}\text { IBSP- } \\
1020\end{array}$ & $\begin{array}{c}367^{\text {bCGJLST }} \\
(70,71 \%)\end{array}$ & $\begin{array}{l}493^{\text {acBEF }} \\
(98,80 \%)\end{array}$ & $\begin{array}{c}207^{\mathrm{cdHI}} \\
(42,95 \%)\end{array}$ & $\begin{array}{c}1067^{\mathrm{aD}} \\
(71,13 \%)\end{array}$ \\
\hline & & & & $\begin{array}{l}\text { VS- } \\
253\end{array}$ & $\begin{array}{l}\text { IBSP- } \\
1020\end{array}$ & $\begin{array}{c}368^{\mathrm{bcBHLMQ}} \\
(70,91 \%)\end{array}$ & $\begin{array}{c}497^{\mathrm{acB}} \\
(99,60 \%)\end{array}$ & $\begin{array}{c}197^{\mathrm{dCl}} \\
(40,87 \%)\end{array}$ & $\begin{array}{l}1062^{\mathrm{aD}} \\
(70,80)\end{array}$ \\
\hline \multirow{4}{*}{ 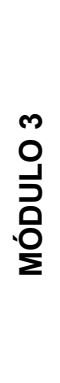 } & \multirow{4}{*}{ 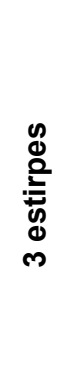 } & NADL & $\begin{array}{c}\text { IBSP- } \\
11\end{array}$ & $\begin{array}{l}\text { VS- } \\
253\end{array}$ & & $\begin{array}{c}363^{\mathrm{bFHLNQ}} \\
(69,94 \%)\end{array}$ & $\begin{array}{c}495^{\mathrm{aB}} \\
(99,20 \%)\end{array}$ & $\begin{array}{c}225^{\mathrm{aBK}} \\
(46,68 \%)\end{array}$ & $\begin{array}{l}1083^{\mathrm{bcFH}} \\
(72,20 \%)\end{array}$ \\
\hline & & NADL & $\begin{array}{c}\text { IBSP- } \\
11\end{array}$ & & $\begin{array}{l}\text { IBSP- } \\
1020\end{array}$ & $\begin{array}{l}372^{\text {aGJMP }}(71,68 \%)\end{array}$ & $\begin{array}{c}497^{\mathrm{aB}} \\
(99,60 \%)\end{array}$ & $\begin{array}{c}228^{\mathrm{aBL}} \\
(47,30 \%)\end{array}$ & $\begin{array}{c}1097^{\mathrm{aBG}} \\
(73,13 \%)\end{array}$ \\
\hline & & NADL & & $\begin{array}{l}\text { VS- } \\
253\end{array}$ & $\begin{array}{l}\text { IBSP- } \\
1020\end{array}$ & $\begin{array}{c}373^{\mathrm{aMO}} \\
(71,87 \%)\end{array}$ & $\begin{array}{c}497^{\mathrm{aB}} \\
(99,60 \%)\end{array}$ & $\begin{array}{l}222^{\mathrm{aCDFKL}} \\
(46,06 \%)\end{array}$ & $\begin{array}{l}1092^{\mathrm{acGH}} \\
(72,80 \%)\end{array}$ \\
\hline & & & $\begin{array}{c}\text { IBSP- } \\
11\end{array}$ & $\begin{array}{l}\text { VS- } \\
253\end{array}$ & $\begin{array}{l}\text { IBSP- } \\
1020\end{array}$ & $\begin{array}{c}369^{\text {abGJLOS }} \\
(71,10 \%)\end{array}$ & $\begin{array}{c}497^{\mathrm{aB}} \\
(99,60 \%)\end{array}$ & $\begin{array}{l}213^{\text {bCDEFG }} \\
(44,19 \%)\end{array}$ & $\begin{array}{c}1079^{\mathrm{EF}} \\
(71,93 \%)\end{array}$ \\
\hline 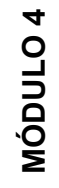 & 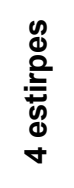 & NADL & $\begin{array}{c}\text { IBSP- } \\
11\end{array}$ & $\begin{array}{l}\text { VS- } \\
253\end{array}$ & $\begin{array}{c}\text { IBSP- } \\
1020\end{array}$ & $\begin{array}{c}373^{\mathrm{BPO}} \\
(71,87 \%)\end{array}$ & $\begin{array}{c}497^{\mathrm{B}} \\
(99,60 \%)\end{array}$ & $\begin{array}{c}229^{B} \\
(47,51 \%)\end{array}$ & $\begin{array}{c}1099^{B} \\
(73,27 \%)\end{array}$ \\
\hline \multicolumn{4}{|c|}{ TOTAL } & & & $\begin{array}{c}519 \\
(100 \%)\end{array}$ & $\begin{array}{c}499 \\
(100 \%)\end{array}$ & $\begin{array}{c}482 \\
(100 \%)\end{array}$ & $\begin{array}{c}1500 \\
(100 \%)\end{array}$ \\
\hline
\end{tabular}


Módulo 1 - Total de animais

Com os resultados obtidos de todos os animais, independente do estado de origem, observou-se que a detecção de anticorpos com a utilização das estirpes de BVDV do genótipo 1, NADL (americano) ou IBSP-11 (isolado nacional) não demonstrou diferença estatística significante $(p=0,363)$. Entretanto, ao comparar as estirpes do genótipo 2, houve diferença significante $(p<0,001)$, com a VS-253 (americana) detectou-se 66,20\% (993/1500) e com a estirpes IBSP-1020 (isolado nacional), 68,67\% (1030/1500). Ainda com a utilização de apenas uma estirpe para o diagnóstico sorológico, observou-se que a IBSP-1020, detectou-se anticorpos em mais animais $(68,67 \%)$ do que quando comparados as outras estirpes utilizadas.

Módulo 2 - Total de animais

A análise dos animais reagentes a pelo menos uma das duas estirpes utilizadas nas VNs, revelou que, 1087 (72,47\%) animais foram reagentes ao NADL ou IBSP-1020, sendo a opção que mais detectou a presença de anticorpos com diferença estatística significante das demais $(p<0,05)$.

Módulo 3 - Total de animais

Quando avaliada a detecção de animais reagentes a pelo menos umas das três estirpes selecionadas, não houve diferença significante $(p=0,180)$ entre $73,13 \%(1097 / 1500)$ de reagentes ao NADL ou IBSP-11 ou IBSP-1020 quando comparado aos 72,80\% (1092/1500) de animais reagentes ao NADL ou VS-253 ou IBSP-1020.

Módulo 4 - Total de animais

Dos 1500 animais estudados, 1099 (73,27\%) foram reagentes a pelo menos uma das quatro estirpes utilizadas neste estudo, apesar de ser a situação em que mais animais sororreagentes foram detectados, não houve diferença estatística 
significante quando comparado com o resultado obtido com três estirpes, sendo elas, NADL ou IBSP-11 ou IBSP-1020 com $1097(73,13 \%)$ reagentes $(p=0,500)$.

Módulo 1 - Animais de Minas Gerais

Nos animais de rebanhos mineiros, os resultados obtidos com apenas uma estirpe foram muito similares, variando de 66,09\% (343/519) animais reagentes para NADL a 68,60\% (356/519) para IBSP-1020.

Módulo 2 - Animais de Minas Gerais

O estudo com duas estirpes revelou que 71,48\% (371/519) dos animais foram reagentes ao NADL ou IBSP-1020, apesar de ser o maior valor de detecção com duas estirpes, não houve diferença estatística significante com IBSP-11 ou IBSP-1020 ( $p=0,219)$ e com VS-253 ou IBSP-1020 $(p=0,453)$.

Módulo 3 - Animais de Minas Gerais

A detecção de anticorpos quando o soro dos animais foi testado com três estirpes diferentes foi melhor quando somados os reagentes para NADL ou VS-253 ou IBSP-1020, alcançando 71,87\% (373/519), apesar disso, não houve diferença significante com o resultado obtido com NADL, IBSP-11, IBSP-1020 (p=1,000) e com IBSP-11, VS-253 e IBSP-1020 $(p=0,125)$.

Módulo 4 - Animais de Minas Gerais

Com a utilização de quatro estirpes, a detecção foi de 71,87\% (373/519), a mesma condição foi encontrada com o uso de três estirpes (NADL, VS-253 e IBSP1020) $(p=1,000)$. 
Módulo 1 - Animais do Mato Grosso do Sul

A análise da detecção de anticorpos com as estirpes de forma individual indicou que, com a estirpe IBSP-1020, 97,39\% (486/499) dos animais foram reagentes, demonstrando diferença significante com os demais $(p<0,001)$.

Módulo 2 - Animais do Mato Grosso do Sul

Considerando os animais sororreagentes a pelo menos uma das duas estirpes selecionadas, 99,60\% (497/499) foram reagentes a NADL ou IBSP-1020 e VS-253 ou IBSP-1020, apesar de ser a frequência de detecção mais alta, não houve diferença estatistica com IBSP-11 ou VS-253 ( $p=0,250)$ e com IBSP-11 ou IBSP-1020 $(p=0,125)$.

Módulo 3 - Animais do Mato Grosso do Sul

Não houve diferença estatística significante independente da combinação de estirpes, três a três, utilizadas. A detecção de anticorpos variou de 99,20\% a $99,60 \%$.

Módulo 4 - Animais do Mato Grosso do Sul

Considerando os animais reagentes a pelos menos uma das quatro estirpes de BVDV utilizadas, 99,60\% (497/499) foram detectados. Contudo, não houve diferença estatística significante com nenhuma das combinações do módulo 3 $(p>0,05)$, nem com as seguintes situações com duas estirpes virais, NADL ou IBSP-1020 ( $p=1,000) ;$ IBSP-11 ou VS-253 ( $p=0,250) ;$ IBSP-11 ou IBSP-1020 $(p=0,125)$ e com VS-253 ou IBSP-1020 $(p=1,000)$.

Módulo 1 - Animais de São Paulo

Os resultados obtidos com cada uma das estirpes, separadamente, foram 39,21\% (189/482) para NADL e IBSP-11, 36,93\% (178/482) para VS-253 e 39,00\% (188/482) para IBSP-1020, não houve diferença significante entre eles $(p>0,05)$. 
Módulo 2 - Animais de São Paulo

Ao combinar os animais reagentes a pelo menos uma duas estirpes, $46,27 \%$ (223/482) animais foram detectados com NADL ou IBSP-11 e 45,44\% (219/482) com NADL ou IBSP-1020, não houve diferença estatística significante entre eles $(p=0,424)$.

Módulo 3 - Animais de São Paulo

$47,30 \%$ (228/482) animais foram reagentes a pelo menos umas das três estirpes, NADL ou IBSP-11 ou IBSP-1020, apesar de ser a maior detecção deste módulo, neste estado, em outras duas situações não houve diferença significante, NADL ou IBSP-11 ou VS-253 $(p=0,375)$ e NADL ou VS-253 ou IBSP-1020 $(p=0,070)$

Módulo 4 - Animais de São Paulo

Com a utilização das quatro estirpes foi detectado o maior número de animais reagentes neste estado, 47,51\% (229/482), embora não tenha demonstrado diferença estatística significante com relação ao resultado encontrado com NADL ou IBSP-11 ou VS-253 $(p=0,125)$ e com NADL ou VS-253 ou IBSP$1020(p=1,000)$.

A frequência de animais reagentes aos quatro vírus, simultaneamente, foi menor, do que com três ou duas estirpes, independente da localidade dos animais, inclusive quando agrupados. Enquanto que, a porcentagem de animais com anticorpos que reagiram ao IBSP-11 e IBSP-1020 (ambos isolados nacionais), foi maior tanto nos animais estudados no MS, em SP e no total, diferentemente, os animais de MG apresentaram este perfil com as estirpes IBSP-11 e VS-253 (Tabela 2). 
Tabela 2 - Deteç̧ão de animais reagentes simultaneamente frente às estirpes de BVDV utilizadas nas reações de virusneutralização - São Paulo - 2009.

\begin{tabular}{|c|c|c|c|c|}
\hline Estirpe viral & MG & MS & SP & Total de animais \\
\hline NADL e IBSP-11 & $\begin{array}{c}333^{\mathrm{ABC}^{*}} \\
(64,16 \%)^{\star *}\end{array}$ & $\begin{array}{c}436^{\text {ABEG }} \\
(87,37 \%)\end{array}$ & $\begin{array}{c}155^{A B} \\
(32,16 \%)\end{array}$ & $\begin{array}{c}924^{\mathrm{AB}} \\
(61,60 \%)\end{array}$ \\
\hline NADL e VS-253 & $\begin{array}{c}336^{\mathrm{BCl}} \\
(64,74 \%)\end{array}$ & $\begin{array}{c}429^{\mathrm{BIK}} \\
(85,97 \%)\end{array}$ & $\begin{array}{c}160^{\mathrm{BC}} \\
(33,20 \%)\end{array}$ & $\begin{array}{c}925^{\mathrm{AB}} \\
(61,67 \%)\end{array}$ \\
\hline NADL e IBSP-1020 & $\begin{array}{c}328^{\text {DEJ }} \\
(63,20 \%)\end{array}$ & $\begin{array}{c}448^{\mathrm{CD}} \\
(89,78 \%)\end{array}$ & $\begin{array}{c}158^{\mathrm{ABD}} \\
(32,78 \%)\end{array}$ & $\begin{array}{c}934^{\mathrm{AB}} \\
(62,27 \%)\end{array}$ \\
\hline IBSP-11 e VS-253 & $\begin{array}{c}347^{\mathrm{CF}} \\
(66,86 \%)\end{array}$ & $\begin{array}{c}430^{\mathrm{BDEFI}} \\
(86,17 \%)\end{array}$ & $\begin{array}{c}158^{A B} \\
(32,78 \%)\end{array}$ & $\begin{array}{c}935^{\mathrm{B}} \\
(62,33 \%)\end{array}$ \\
\hline IBSP-11 e IBSP-1020 & $\begin{array}{c}339^{\mathrm{BFGI}} \\
(65,32 \%)\end{array}$ & $\begin{array}{c}457^{\mathrm{C}} \\
(91,58 \%)\end{array}$ & $\begin{array}{c}170^{\mathrm{CD}} \\
(35,27 \%)\end{array}$ & $\begin{array}{c}966^{\mathrm{C}} \\
(64,40 \%)\end{array}$ \\
\hline VS-253 e IBSP-1020 & $\begin{array}{c}343^{\mathrm{BF}} \\
(66,09 \%)\end{array}$ & $\begin{array}{c}449^{\mathrm{CG}} \\
(89,98 \%)\end{array}$ & $\begin{array}{c}169^{\mathrm{C}} \\
(35,06 \%)\end{array}$ & $\begin{array}{c}961^{\mathrm{C}} \\
(64,07 \%)\end{array}$ \\
\hline NADL e IBSP-11e VS-253 & $\begin{array}{c}330^{\mathrm{ADGH}} \\
(63,58 \%)\end{array}$ & $\begin{array}{c}407^{\mathrm{H}} \\
(81,56 \%)\end{array}$ & $\begin{array}{c}143^{\mathrm{E}} \\
(29,67 \%)\end{array}$ & $\begin{array}{c}880^{\mathrm{D}} \\
(58,67 \%)\end{array}$ \\
\hline NADL e IBSP-11e IBSP-1020 & $\begin{array}{c}323^{\mathrm{EHK}} \\
(62,24 \%)\end{array}$ & $\begin{array}{c}429^{1 \mathrm{~J}} \\
(85,97 \%)\end{array}$ & $\begin{array}{c}145^{\mathrm{E}} \\
(30,08 \%)\end{array}$ & $\begin{array}{c}897^{\mathrm{E}} \\
(59,80 \%)\end{array}$ \\
\hline NADL e VS-253 e IBSP-1020 & $\begin{array}{c}326^{\mathrm{DHK}} \\
(62,81 \%)\end{array}$ & $\begin{array}{c}418^{\mathrm{gFJ}} \\
(83,77 \%)\end{array}$ & $\begin{array}{c}154^{\mathrm{A}} \\
(31,95 \%)\end{array}$ & $\begin{array}{c}898^{\mathrm{E}} \\
(59,87 \%)\end{array}$ \\
\hline IBSP-11 e VS-253 e IBSP-1020 & $\begin{array}{c}336^{\text {AlJ }} \\
(64,74 \%)\end{array}$ & $\begin{array}{c}426^{\text {AJK }} \\
(84,77 \%)\end{array}$ & $\begin{array}{c}156^{A B} \\
(32,37 \%)\end{array}$ & $\begin{array}{c}915^{\mathrm{AE}} \\
(61,00 \%)\end{array}$ \\
\hline $\begin{array}{l}\text { NADL e IBSP-11 e VS-253 e IBSP- } \\
1020\end{array}$ & $\begin{array}{c}321 \mathrm{~K} \\
(61,85 \%) \\
\end{array}$ & $\begin{array}{c}400^{\mathrm{L}} \\
(80,16 \%) \\
\end{array}$ & $\begin{array}{c}142^{\mathrm{E}} \\
(29,46 \%) \\
\end{array}$ & $\begin{array}{c}864^{\mathrm{F}} \\
(57,60 \%) \\
\end{array}$ \\
\hline Número de Animais & 519 & 499 & 482 & 1500 \\
\hline
\end{tabular}

Os títulos de anticorpos variaram de $<10$ (não reagente) a 5120 , e sua distribuição para todos os animais aos quatro vírus utilizados (BVDV-1 NADL, BVDV-1 IBSP11, BVDV-2 VS253 e BVDV-2 IBSP1020) está descrita na tabela 3 e gráfico 5.

Os títulos de anticorpos que obtiveram a maior porcentagem de animais reagentes foram 40 para NADL (16,8\%) e IBSP-11 (14,73\%), 160 para VS-253 $(14,80 \%)$ e IBSP-1020 (18,13\%) (Tabela 3).

A distribuição de anticorpos dos animais de MG está apresentada na tabela 4 e gráfico 6, sendo que a maioria dos sororreagentes apresentou título 40 para NADL (13,87\%), 80 para IBSP-11 (12,91\%) e VS-253 (17,73\%), e 160 para IBSP$1020(18,88 \%)$. 
Tabela 3 - Distribuição dos títulos de anticorpos neutralizantes presentes no soro de 1500 animais frente às estirpes virais (BVDV-1 NADL, BVDV-1 IBSP11, BVDV-2 VS253 e BVDV-2 IBSP1020) - São Paulo - 2009.

\begin{tabular}{ccccc}
\hline $\begin{array}{c}\text { TíTULO DE } \\
\text { ANTICORPOS }\end{array}$ & $\begin{array}{c}\text { BVDV-1 } \\
\text { NADL }\end{array}$ & $\begin{array}{c}\text { BVDV-1 } \\
\text { IBSP-11 }\end{array}$ & $\begin{array}{c}\text { BVDV-2 } \\
\text { VS-253 }\end{array}$ & $\begin{array}{c}\text { BVDV-2 } \\
\text { IBSP1020 }\end{array}$ \\
\hline$<\mathbf{1 0}$ & 509 & 497 & 507 & 470 \\
& $(33,90 \%)$ & $(33,10 \%)$ & $(33,80 \%)$ & $(31,3 \%)$ \\
$\mathbf{1 0}$ & 157 & 120 & 74 & 70 \\
& $(10,47 \%)$ & $(8,00 \%)$ & $(4,93 \%)$ & $(4,67 \%)$ \\
$\mathbf{2 0}$ & 188 & 173 & 146 & 92 \\
& $(12,53 \%)$ & $(11,53 \%)$ & $(9,73 \%)$ & $(6,13 \%)$ \\
$\mathbf{4 0}$ & 252 & 221 & 174 & 137 \\
& $(16,8 \%)$ & $(14,73 \%)$ & $(11,60 \%)$ & $(9,13 \%)$ \\
$\mathbf{8 0}$ & 156 & 205 & 199 & 177 \\
& $(10,40 \%)$ & $(13,67 \%)$ & $(13,27 \%)$ & $(11,80 \%)$ \\
$\mathbf{1 6 0}$ & 107 & 128 & 222 & 272 \\
& $(7,13 \%)$ & $(8,53 \%)$ & $(14,80 \%)$ & $(18,13 \%)$ \\
$\mathbf{3 2 0}$ & 62 & 76 & 108 & 172 \\
& $(4,13 \%)$ & $(5,07 \%)$ & $(7,20 \%)$ & $(11,47 \%)$ \\
$\mathbf{6 4 0}$ & 30 & 46 & 50 & 87 \\
& $(2,00 \%)$ & $(3,07 \%)$ & $(3,33 \%)$ & $(5,80 \%)$ \\
$\mathbf{1 2 8 0}$ & 30 & 25 & 11 & 17 \\
& $(2,00 \%)$ & $(1,67 \%)$ & $(0,73 \%)$ & $(1,13 \%)$ \\
$\mathbf{2} \mathbf{2 5 6 0}$ & 6 & 7 & 8 & 2 \\
& $(0,40 \%)$ & $(0,47 \%)$ & $(0,53 \%)$ & $(0,13 \%)$ \\
$\mathbf{5 1 2 0}$ & 3 & 6 & 1 & 4 \\
& $(0,20 \%)$ & $(0,40 \%)$ & $(0,07 \%)$ & $(0,27 \%)$ \\
\hline \multirow{2}{*}{ TOTAL } & 1500 & 1500 & 1500 & 1500 \\
\hline \multirow{5}{*}{} & & & & \\
\hline
\end{tabular}

600

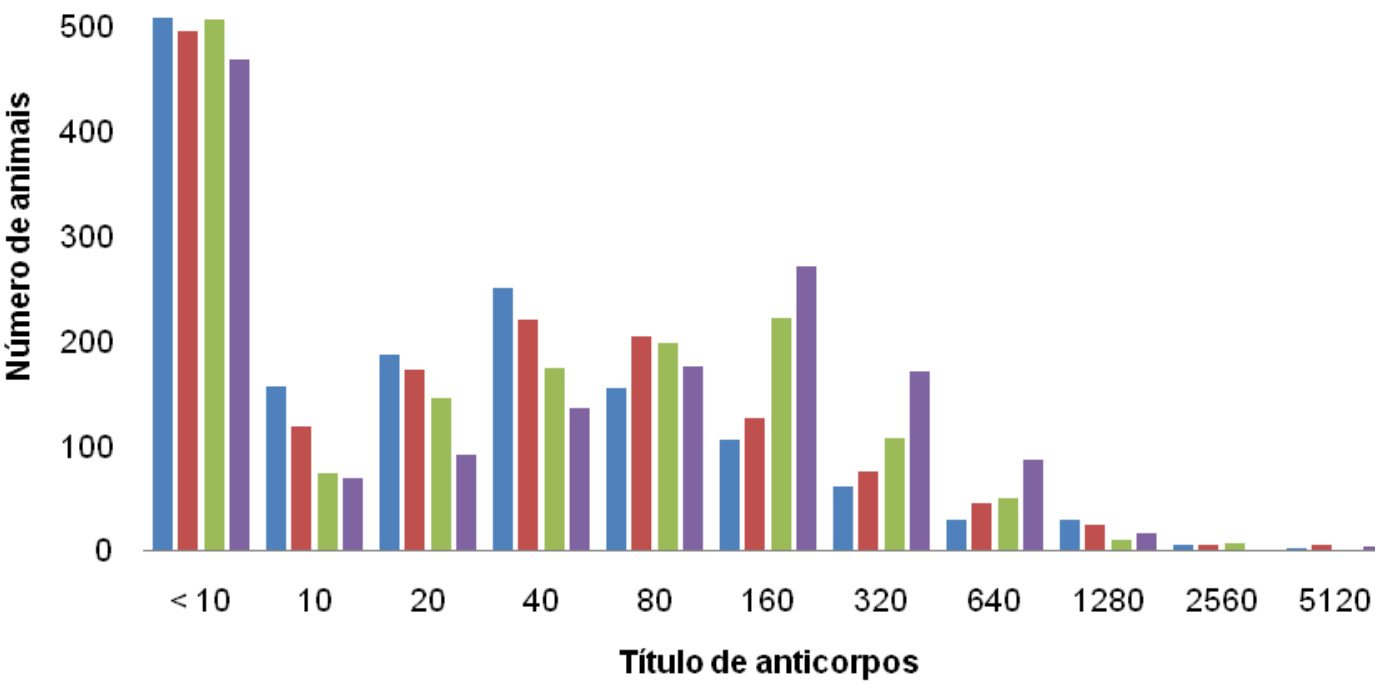

- BVDV-1 NADL "BVDV-1 IBSP-11 -BVDV-2 VS-253 "BVDV-2 IBSP-1020

Gráfico 5 - Distribuição dos títulos de anticorpos neutralizantes presentes no soro de 1500 animais frente às estirpes virais (BVDV-1 NADL, BVDV-1 IBSP11, BVDV-2 VS253 e BVDV-2 IBSP1020) - São Paulo - 2009. 
Tabela 4 - Distribuição dos títulos de anticorpos neutralizantes no soro dos animais do Estado de Minas Gerais frente às quatro estirpes virais - São Paulo - 2009.

\begin{tabular}{|c|c|c|c|c|c|}
\hline & $\begin{array}{l}\text { TÍTULO DE } \\
\text { ANTICORPOS }\end{array}$ & $\begin{array}{l}\text { BVDV-1 } \\
\text { NADL }\end{array}$ & $\begin{array}{l}\text { BVDV-1 } \\
\text { IBSP-11 }\end{array}$ & $\begin{array}{l}\text { BVDV-2 } \\
\text { VS-253 }\end{array}$ & $\begin{array}{c}\text { BVDV-2 } \\
\text { IBSP1020 }\end{array}$ \\
\hline \multirow{12}{*}{$\begin{array}{l}\text { MINAS } \\
\text { GERAIS }\end{array}$} & $<10$ & $\begin{array}{c}176 \\
(33,91 \%)\end{array}$ & $\begin{array}{c}169 \\
(32,56 \%)\end{array}$ & $\begin{array}{c}164 \\
(31,60 \%)\end{array}$ & $\begin{array}{c}163 \\
(31,41 \%)\end{array}$ \\
\hline & 10 & $\begin{array}{c}37 \\
(7,13 \%)\end{array}$ & $\begin{array}{c}36 \\
(6,94 \%)\end{array}$ & $\begin{array}{c}17 \\
(3,28 \%)\end{array}$ & $\begin{array}{c}17 \\
(3,28 \%)\end{array}$ \\
\hline & 20 & $\begin{array}{c}65 \\
(12,52 \%)\end{array}$ & $\begin{array}{c}58 \\
(11,18 \%)\end{array}$ & $\begin{array}{c}33 \\
(6,36 \%)\end{array}$ & $\begin{array}{c}37 \\
(7,13 \%)\end{array}$ \\
\hline & 40 & $\begin{array}{c}72 \\
(13,87 \%)\end{array}$ & $\begin{array}{c}66 \\
(12,72 \%)\end{array}$ & $\begin{array}{c}63 \\
(12,14 \%)\end{array}$ & $\begin{array}{c}59 \\
(11,37 \%)\end{array}$ \\
\hline & 80 & $\begin{array}{c}50 \\
(9,63 \%)\end{array}$ & $\begin{array}{c}67 \\
(12,91 \%)\end{array}$ & $\begin{array}{c}92 \\
(17,73 \%)\end{array}$ & $\begin{array}{c}69 \\
(13,29 \%)\end{array}$ \\
\hline & 160 & $\begin{array}{c}40 \\
(7,71 \%)\end{array}$ & $\begin{array}{c}38 \\
(7,32 \%)\end{array}$ & $\begin{array}{c}87 \\
(16,76 \%)\end{array}$ & $\begin{array}{c}98 \\
(18,88 \%)\end{array}$ \\
\hline & 320 & $\begin{array}{c}31 \\
(5,96 \%)\end{array}$ & $\begin{array}{c}33 \\
(6,36 \%)\end{array}$ & $\begin{array}{c}37 \\
(7,13 \%)\end{array}$ & $\begin{array}{c}44 \\
(8,48 \%)\end{array}$ \\
\hline & 640 & $\begin{array}{c}18 \\
(3,47 \%)\end{array}$ & $\begin{array}{c}25 \\
(4,82 \%)\end{array}$ & $\begin{array}{c}16 \\
(3,08 \%)\end{array}$ & $\begin{array}{c}22 \\
(4,24 \%)\end{array}$ \\
\hline & 1280 & $\begin{array}{c}26 \\
(5,01 \%)\end{array}$ & $\begin{array}{c}18 \\
(3,47 \%)\end{array}$ & $\begin{array}{c}5 \\
(0,96 \%)\end{array}$ & $\begin{array}{c}4 \\
(0,77 \%)\end{array}$ \\
\hline & 2560 & $\begin{array}{c}3 \\
(0,58 \%)\end{array}$ & $\begin{array}{c}5 \\
(0,96 \%)\end{array}$ & $\begin{array}{c}5 \\
(0,96 \%)\end{array}$ & $\begin{array}{c}2 \\
(0,40 \%)\end{array}$ \\
\hline & 5120 & $\begin{array}{c}1 \\
(0,19 \%)\end{array}$ & $\begin{array}{c}4 \\
(0,77 \%)\end{array}$ & $\begin{array}{c}0 \\
(0,00 \%)\end{array}$ & $\begin{array}{c}4 \\
(0,77 \%)\end{array}$ \\
\hline & TOTAL & 519 & 519 & 519 & 519 \\
\hline
\end{tabular}

\section{0}

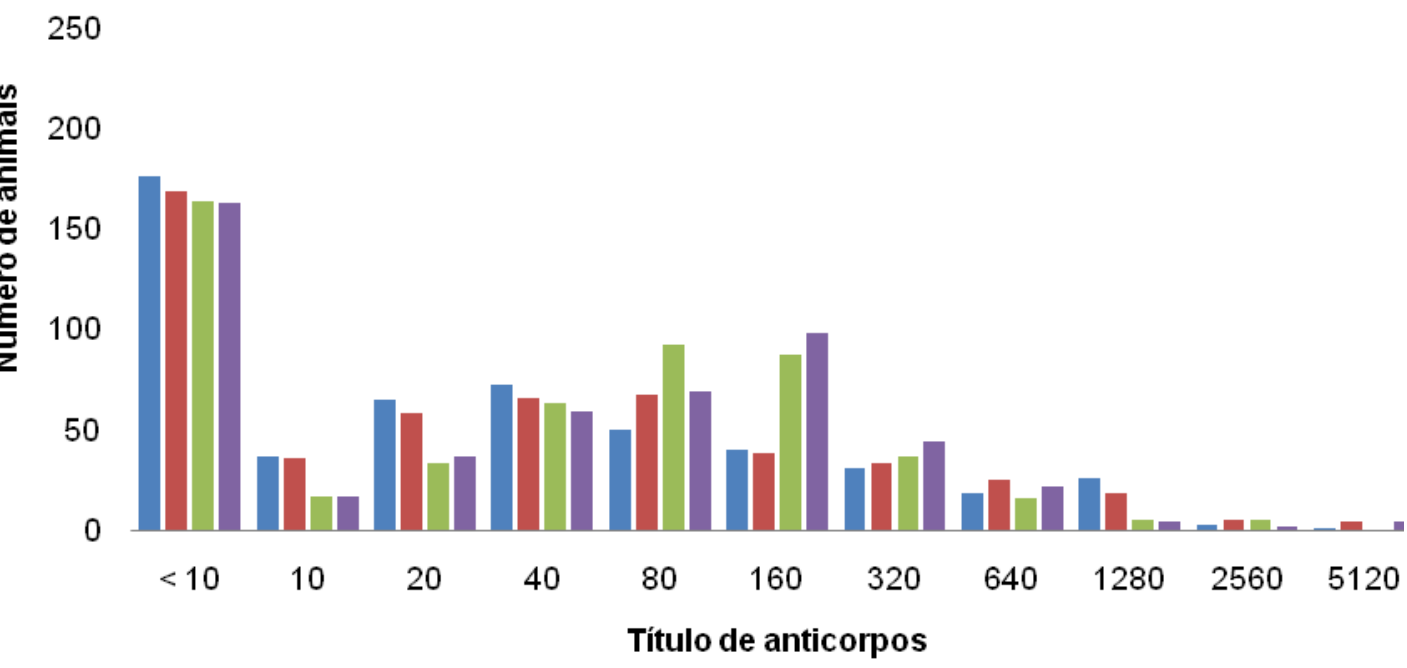

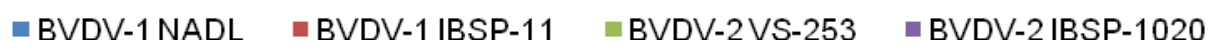

Gráfico 6 - Distribuição dos títulos de anticorpos neutralizantes no soro dos animais do Estado de Minas Gerais (total de 519 animais) frente às quatro estirpes virais São Paulo - 2009. 
No Estado do MS, $29,86 \%$ dos animais tiveram título de anticorpos 40 frente ao NADL, 24,05\% com título 40 ao IBSP-11, e com título de anticorpos 160, $21,44 \%$ de reagentes para VS-253 e 28,86\% para IBSP-1020 (Tabela 5 e Gráfico 7).

Em SP, 8,51\% dos animais tiveram título 10 para o NADL, 7,68\% com título 20 para IBSP-11, com título 40, 9,54\% para VS-253 e 9,75\% para IBSP-1020 (Tabela 6 e Gráfico 8). 
Tabela 5 - Distribuição dos títulos de anticorpos neutralizantes presentes no soro dos animais do Estado de Mato Grosso do Sul (total de 499 animais) frente às quatro estirpes virais - São Paulo - 2009.

\begin{tabular}{|c|c|c|c|c|c|}
\hline & $\begin{array}{c}\text { TíTULO DE } \\
\text { ANTICORPOS }\end{array}$ & $\begin{array}{l}\text { BVDV-1 } \\
\text { NADL }\end{array}$ & $\begin{array}{l}\text { BVDV-1 } \\
\text { IBSP-11 }\end{array}$ & $\begin{array}{l}\text { BVDV-2 } \\
\text { VS-253 }\end{array}$ & $\begin{array}{c}\text { BVDV-2 } \\
\text { IBSP1020 }\end{array}$ \\
\hline \multirow{12}{*}{$\begin{array}{c}\text { MATO } \\
\text { GROSSO } \\
\text { DO SUL }\end{array}$} & $<10$ & $\begin{array}{c}40 \\
(8,02 \%)\end{array}$ & $\begin{array}{c}34 \\
(6,81 \%)\end{array}$ & $\begin{array}{c}39 \\
(7,82 \%)\end{array}$ & $\begin{array}{c}13 \\
(2,61 \%)\end{array}$ \\
\hline & 10 & $\begin{array}{c}79 \\
(15,83 \%)\end{array}$ & $\begin{array}{c}48 \\
(9,62 \%)\end{array}$ & $\begin{array}{c}42 \\
(8,42 \%)\end{array}$ & $\begin{array}{c}25 \\
(5,01 \%)\end{array}$ \\
\hline & 20 & $\begin{array}{c}98 \\
(19,64 \%)\end{array}$ & $\begin{array}{c}78 \\
(15,63 \%)\end{array}$ & $\begin{array}{c}69 \\
(13,83 \%)\end{array}$ & $\begin{array}{c}20 \\
(4,01 \%)\end{array}$ \\
\hline & 40 & $\begin{array}{c}149 \\
(29,86 \%)\end{array}$ & $\begin{array}{c}120 \\
(24,05 \%)\end{array}$ & $\begin{array}{c}65 \\
(13,03 \%)\end{array}$ & $\begin{array}{c}31 \\
(6,21)\end{array}$ \\
\hline & 80 & $\begin{array}{c}78 \\
(15,63 \%)\end{array}$ & $\begin{array}{c}113 \\
(22,65 \%)\end{array}$ & $\begin{array}{c}79 \\
(15,83 \%)\end{array}$ & $\begin{array}{c}73 \\
(14,63 \%)\end{array}$ \\
\hline & 160 & $\begin{array}{c}41 \\
(8,22 \%)\end{array}$ & $\begin{array}{c}65 \\
(13,03 \%)\end{array}$ & $\begin{array}{c}107 \\
(21,44 \%)\end{array}$ & $\begin{array}{c}144 \\
(28,86 \%)\end{array}$ \\
\hline & 320 & $\begin{array}{c}13 \\
(2,61 \%)\end{array}$ & $\begin{array}{c}29 \\
(5,81 \%)\end{array}$ & $\begin{array}{c}58 \\
(11,62 \%)\end{array}$ & $\begin{array}{c}119 \\
(23,85 \%)\end{array}$ \\
\hline & 640 & $\begin{array}{c}1 \\
(0,20 \%)\end{array}$ & $\begin{array}{c}12 \\
(2,40 \%)\end{array}$ & $\begin{array}{c}31 \\
(6,21 \%)\end{array}$ & $\begin{array}{c}62 \\
(12,42 \%)\end{array}$ \\
\hline & 1280 & $\begin{array}{c}0 \\
(0,00 \%)\end{array}$ & $\begin{array}{c}0 \\
(0,00 \%)\end{array}$ & $\begin{array}{c}5 \\
(1,00 \%)\end{array}$ & $\begin{array}{c}12 \\
(2,40 \%)\end{array}$ \\
\hline & 2560 & $\begin{array}{c}0 \\
(0,00 \%)\end{array}$ & $\begin{array}{c}0 \\
(0,00 \%)\end{array}$ & $\begin{array}{c}3 \\
(0,60 \%)\end{array}$ & $\begin{array}{c}0 \\
(0,00 \%)\end{array}$ \\
\hline & 5120 & $\begin{array}{c}0 \\
(0,00 \%) \\
\end{array}$ & $\begin{array}{c}0 \\
(0,00 \%) \\
\end{array}$ & $\begin{array}{c}1 \\
(0,20 \%) \\
\end{array}$ & $\begin{array}{c}0 \\
(0,00 \%) \\
\end{array}$ \\
\hline & TOTAL & 499 & 499 & 499 & 499 \\
\hline
\end{tabular}

300

250

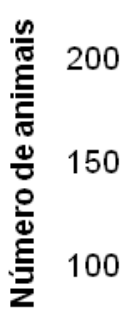

50

0

11

$\begin{array}{lllllll}<10 & 10 & 20 & 40 & 80 & 160 & 320\end{array}$

$640 \quad 1280 \quad 2560 \quad 5120$

Título de anticorpos

$\because$ BVDV-1 NADL $\quad$ BVDV-1 IBSP-11 $\because$ BVDV-2 VS-253 $\quad$ BVDV-2 IBSP-1020

Gráfico 7 - Distribuição dos títulos de anticorpos neutralizantes presentes no soro dos animais do Estado de Mato Grosso do Sul (total de 499 animais) frente às quatro estirpes virais - São Paulo - 2009. 
Tabela 6 - Distribuição dos títulos de anticorpos neutralizantes presentes no soro dos animais do Estado de São Paulo (total de 482 animais) frente às quatro estirpes virais - São Paulo - 2009.

\begin{tabular}{|c|c|c|c|c|c|}
\hline & $\begin{array}{c}\text { TíTULO DE } \\
\text { ANTICORPOS }\end{array}$ & $\begin{array}{l}\text { BVDV-1 } \\
\text { NADL }\end{array}$ & $\begin{array}{l}\text { BVDV-1 } \\
\text { IBSP-11 }\end{array}$ & $\begin{array}{l}\text { BVDV-2 } \\
\text { VS-253 }\end{array}$ & $\begin{array}{c}\text { BVDV-2 } \\
\text { IBSP1020 }\end{array}$ \\
\hline \multirow{12}{*}{$\begin{array}{l}\text { SÃO } \\
\text { PAULO }\end{array}$} & $<10$ & $\begin{array}{c}293 \\
(60,79)\end{array}$ & $\begin{array}{c}293 \\
(60,79)\end{array}$ & $\begin{array}{c}304 \\
(63,07 \%)\end{array}$ & $\begin{array}{c}294 \\
(61,00 \%)\end{array}$ \\
\hline & 10 & $\begin{array}{c}41 \\
(8,51 \%)\end{array}$ & $\begin{array}{c}36 \\
(7,47 \%)\end{array}$ & $\begin{array}{c}15 \\
(3,11 \%)\end{array}$ & $\begin{array}{c}28 \\
(5,81 \%)\end{array}$ \\
\hline & 20 & $\begin{array}{c}25 \\
(5,19 \%)\end{array}$ & $\begin{array}{c}37 \\
(7,68 \%)\end{array}$ & $\begin{array}{c}44 \\
(9,13 \%)\end{array}$ & $\begin{array}{c}35 \\
(6,64 \%)\end{array}$ \\
\hline & 40 & $\begin{array}{c}31 \\
(6,43 \%)\end{array}$ & $\begin{array}{c}35 \\
(6,64 \%)\end{array}$ & $\begin{array}{c}46 \\
(9,54 \%)\end{array}$ & $\begin{array}{c}47 \\
(9,75 \%)\end{array}$ \\
\hline & 80 & $\begin{array}{c}28 \\
(5,81 \%)\end{array}$ & $\begin{array}{c}25 \\
(5,19 \%)\end{array}$ & $\begin{array}{c}28 \\
(5,81 \%)\end{array}$ & $\begin{array}{c}35 \\
(6,64 \%)\end{array}$ \\
\hline & 160 & $\begin{array}{c}26 \\
(5,39 \%)\end{array}$ & $\begin{array}{c}25 \\
(5,19 \%)\end{array}$ & $\begin{array}{c}28 \\
(5,81 \%)\end{array}$ & $\begin{array}{c}30 \\
(6,22 \%)\end{array}$ \\
\hline & 320 & $\begin{array}{c}18 \\
(3,73 \%)\end{array}$ & $\begin{array}{c}14 \\
(2,90 \%)\end{array}$ & $\begin{array}{c}13 \\
(2,70 \%)\end{array}$ & $\begin{array}{c}9 \\
(1,87 \%)\end{array}$ \\
\hline & 640 & $\begin{array}{c}11 \\
(2,28 \%)\end{array}$ & $\begin{array}{c}9 \\
(1,87 \%)\end{array}$ & $\begin{array}{c}3 \\
(0,62 \%)\end{array}$ & $\begin{array}{c}3 \\
(0,62 \%)\end{array}$ \\
\hline & 1280 & $\begin{array}{c}4 \\
(0,83 \%)\end{array}$ & $\begin{array}{c}7 \\
(1,45 \%)\end{array}$ & $\begin{array}{c}1 \\
(0,21 \%)\end{array}$ & $\begin{array}{c}1 \\
(0,21 \%)\end{array}$ \\
\hline & 2560 & $\begin{array}{c}3 \\
(0,62 \%)\end{array}$ & $\begin{array}{c}2 \\
(0,41 \%)\end{array}$ & $\begin{array}{c}0 \\
(0 \%)\end{array}$ & $\begin{array}{c}0 \\
(0 \%)\end{array}$ \\
\hline & 5120 & $\begin{array}{c}2 \\
(0,41 \%)\end{array}$ & $\begin{array}{c}2 \\
(0,41 \%)\end{array}$ & $\begin{array}{c}0 \\
(0 \%)\end{array}$ & $\begin{array}{c}0 \\
(0 \%)\end{array}$ \\
\hline & TOTAL & 482 & 482 & 482 & 482 \\
\hline
\end{tabular}

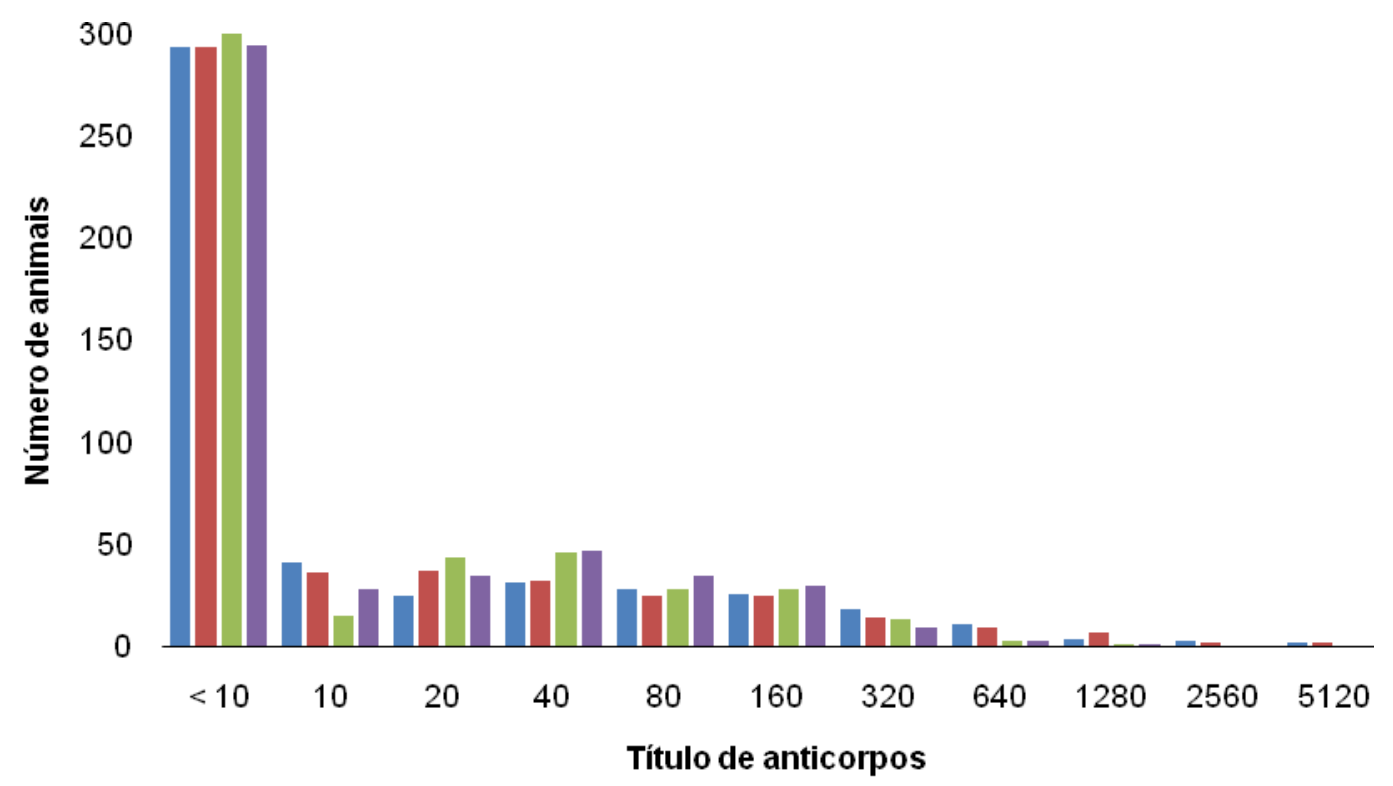

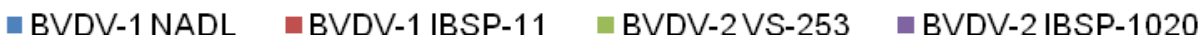

Gráfico 8 - Distribuição dos títulos de anticorpos neutralizantes presentes no soro dos animais do Estado de São Paulo (total de 482 animais) frente às quatro estirpes virais - São Paulo - 2009. 
A comparação dos títulos de anticorpos da amostra de cada animal frente quatro estirpes de BVDV foi realizada pelo teste de Wilcoxon. Houve discordância entre os títulos de anticorpos detectados contra as estirpes NADL e IBSP-1020 $(p=0,006)$ dos animais dos rebanhos mineiros, entre NADL e IBSP-11, NADL e VS253, NADL e IBSP-1020, IBSP-11 e VS-253, IBSP-11 e IBSP-1020 e entre VS-253 e IBSP-1020 $(p<0,001)$ dos animais do Estado do Mato Grosso do Sul. Nos animais de São Paulo, houve diferença entre NADL e VS-253 e NADL e IBSP-1020 $(p<0,001)$, entre IBSP-11 e VS-253 $(p=0,007)$ e entre IBSP-11e IBSP-1020 $(p=0,010)$. No total dos animais todas as combinações foram diferentes estatisticamente $(p \leq 0,001)$ (Tabela 7$)$.

Tabela 7 - Comparação dos títulos de anticorpos entre as estirpes, duas a duas, de BVDV dos animais do Estado de Minas Gerais, Mato Grosso do Sul, São Paulo e no total geral - São Paulo - 2009.

\begin{tabular}{cccccc}
\hline \multicolumn{2}{c}{ Estirpes de BVDV } & MG & MS & SP & Total \\
\hline NADL & IBSP-11 & 0,404 & $<0,001^{*}$ & 0,061 & $0,001^{*}$ \\
NADL & VS-253 & 0,237 & $<0,001^{*}$ & $<0,001^{*}$ & $<0,001^{*}$ \\
NADL & IBSP-1020 & $0,006^{*}$ & $<0,001^{*}$ & $<0,001^{*}$ & $<0,001^{*}$ \\
IBSP-11 & VS-253 & 0,981 & $<0,001^{*}$ & $0,007^{*}$ & $<0,001^{*}$ \\
IBSP-11 & IBSP-1020 & 0,142 & $<0,001^{*}$ & 0,010 & $<0,001^{*}$ \\
VS-253 & IBSP-1020 & 0,088 & $<0,001^{*}$ & 0,780 & $<0,001^{*}$ \\
\hline
\end{tabular}

* Diferença significante pelo teste de Wilcoxon e com correção de Bonferroni $(p<0,0083)$. 


\section{DISCUSSÃO}

Os primeiros relatos da doença no Brasil datam de 1968 (CÔRREA; NETTO; BARROS, 1968), e os primeiros levantamentos sorológicos surgiram a partir da década de 70 (WIZIGMANN et al., 1971). Desde então, houve diversas publicações sobre a presença da infecção no país (FIGUEIREDO et al., 1997; BOTTON et al., 1998; CANAL et al., 1998; PITUCO; DEL FAVA, 1998; ROEHE et al., 1998; RICHTZENHAIN et al., 1999; DIAS; SAMARA, 2003; SAMARA; DIAS; MOREIRA, 2004; FLORES et al., 2005). Porém, são poucos os relatos que enfocam a pesquisa de anticorpos neutralizantes especificamente contra BVDV-1 e BVDV-2.

Os laboratórios de diagnóstico seguem os protocolos recomendados pela Organização Mundial de Saúde Animal (OIE), por ser este um órgão de referência internacional com objetivo de coletar, analisar e divulgar informações científicas atualizadas sobre o controle de doenças que acometem animais.

Para diagnóstico da BVD a OIE (2008) recomenda a técnica de VN para detecção de anticorpos específicos contra BVDV. Contudo, não há um vírus padrão de referência nacional ou internacional que possa ser utilizado. Esta falta de padronização poderia explicar a discrepância nos resultados emitidos por diferentes laboratórios para uma mesma amostra (RIDPATH, 1994), preocupação esta que motivou o presente estudo. Com a proposta de verificar a presença de anticorpos, sua mensuração e neutralização cruzada, amostras de 1500 bovinos foram analisadas frente a quatro estirpes de BVDV, pela VN. Os animais são provenientes de três estados brasileiros - MG, MS e SP, essas amostras não são representativas de cada estado, e sim dos rebanhos estudados.

$\mathrm{Na}$ amostragem utilizada neste estudo de $66,07 \%$ a $68,67 \%$ animais foram reagentes ao BVDV, estes dados estão de acordo com outros trabalhos nacionais sobre a ocorrência de anticorpos em bovinos (PELLEGRIN et al., 1997; BOTTON et al., 1998; PITUCO; DEL FAVA, 1998; DIAS; SAMARA, 2003; NORONHA et al., 2003).

Ao analisar os animais de acordo com o estado de origem e sistema de criação, independente da estirpe de BVDV utilizada no teste de VN, a maior frequência de anticorpos foi obtida nos animais estudados no Estado do MS, seguida por MG e SP, essas diferenças podem ser devido ao sistema de criação e 
manejo. A amostragem utilizada não é representativa do estado em questão, com os resultados pode-se perceber que o sistema de criação e manejo influenciaram mais na frequência de ocorrência de animais reagentes ao BVDV do que a própria região de origem destes bovinos. Os animais do MS são criados em sistema extensivo, e os de MG e SP intensivo e semi-intensivo.

Segundo Houe, 1999, o sistema de criação extensivo não favorece a disseminação do vírus, pois a transmissão ocorre principalmente por contato direto com um animal infectado (BROWNLIE et al., 1987). Porém, o presente estudo encontrou um perfil diferente, 99,60\% (497/499) de sororreagentes nos animais do Estado do MS, criados em sistema extensivo. Isto pode ser explicado pela introdução de animais no rebanho sem que seja realizado estudo prévio para pesquisa de animais Pls.

Vale lembrar que animais Pls são a principal fonte de manutenção e transmissão do vírus (BAKER, 1995), e a prevalência nos rebanhos pode variar de 1 a 2\% (BROWNLIE, 1990; OLIVEIRA, 1996; HOUE, 1999), se presentes em um rebanho com sistema de criação extensivo podem permanecer por tempo suficiente para eliminar o vírus de forma constante, sem que sejam identificados e descartados. A maioria dos animais Pls nasce debilitada e por esse motivo sucumbe nos dois primeiros anos de vida. No entanto grande parte destes animais podem não apresentar sintomas, dificultando seu reconhecimento em criações extensivas, e assim, permanecem no rebanho (BOLIN, 1990). Acredita-se que este seja o motivo pela maior frequência encontrada nos rebanhos estudados do Estado de MS. Animais transitoriamente infectados e animais susceptíveis também favorecem a permanência do vírus no rebanho, pois bovinos com BVD aguda excretam pequenas quantidade de vírus durante poucos dias (BROWNLIE et al., 1987; TREMBLAY, 1996), podendo infectar outros animais, porém, de maneira menos eficiente (MEYLING; HOUE; JENSEN, 1990). Estes dados demonstram a necessidade de avaliar animais introduzidos nos rebanhos bovinos, a fim de evitar a disseminação da infecção.

Além disso, uma justificativa para a maior frequência de animais reagentes encontrada nos rebanhos oriundos do MS é que, animais da raça Nelore, criados extensivamente para produção de carne, são submetidos a práticas populacionais de manejo, por exemplo, todos os bezerros são desmamados em um mesmo período. Essa peculiariedade faz com que bezerros, infectados ou não, podendo ter 
alguns Pls, convivam estreitamente com fêmeas adultas potencialmente suscetíveis, mantendo mais ativo o ciclo da doença no rebanho (WITTUM et al., 2001). Enquanto, nos rebanhos leiteiros a separação dos bezerros e vacas ocorre mais precocemente, e também o descarte de bezerros machos após o nascimento restringe o risco de PI aos suscetíveis (LINDBERG, 2002).

Não foram encontrados estudos na literatura consultada sobre a ocorrência de animais sororreagentes pela técnica de VN, no Estado do MS. Porém, em um estudo semelhante utilizando o método de ELISA, Richtzeinhain (1999) encontrou $83,67 \%$ de animais reagentes neste estado.

Os animais estudados em MG são mantidos em sistema de criação intensivo ou semi-intensivo. Segundo Houe (1999), o sistema de criação intensivo favorece maior disseminação do vírus. Neste estudo a porcentagem de animais reagentes a pelo menos uma estirpe foi 71,87\% (373/519), da mesma forma, Dias (2008) encontrou $60 \%$ de reagentes no mesmo estado e em sistema de criação semelhante, contudo observou também que um rebanho contendo dois animais Pls, a porcentagem de reagentes foi $94,00 \%$.

Apesar dos sistemas de criação dos animais estudados em SP, serem os mesmos de MG, ou seja, intensivo e semi-intensivo, nos rebanhos paulistas estudados havia grande preocupação com o ingresso de novos bovinos, processo este que, indiretamente controlaria a entrada de animais PI nos rebanhos. Isso pode explicar a menor frequência observada, 47,51\% (229/482) reagentes ao BVDV, se comparada às outras regiões estudadas aqui. Pituco e Del Fava (1998) analisaram 493 touros de uma central de inseminação e encontraram 40,8 \% de reagentes ao BVDV-1 NADL, pela técnica de VN, este resultado pode ser comparado ao deste estudo visto que, o controle de entrada de animais na central é rigoroso não permitindo o ingresso de animal PI. Mesmo com controle não tão severo quanto à entrada de animais Pls nas propriedades estudadas, a porcentagem de animais reagentes ao BVDV foi muito próxima. Um estudo encontrou $14,30 \%$ de animais reagentes em um rebanho leiteiro, em MG, que não possuía animais $\mathrm{PI}$, devido à dinâmica de produção dessa propriedade, a possível aquisição de animais contaminados ou até persistentemente infectados é muito baixa (NOGUEIRA, 2003).

De acordo com a literatura, diversos fatores podem interferir na ocorrência de anticorpos contra BVDV ou na sua detecção, dentre eles, a metodologia de 
diagnóstico utilizada, o estado ou região, população bovina, manejo dos animais testados, trânsito de animais e diversidade regional dos vírus (KRAHL et al., 1997; PITUCO; DEL FAVA, 1998; DIAS; SAMARA, 2003).

Esses resultados, por si só, trazem aspectos interessantes por sinalizar que os riscos da BVD para os animais em criação extensiva podem ser mais expressivos do que para os animais submetidos ao sistema intensivo, considerando sempre as quatro estirpes utilizadas nos testes de VN.

Importante ferramenta no diagnóstico da BVD, a técnica de VN é amplamente utilizada para detecção de anticorpos contra o vírus, (FULTON et al., 1995; OIE 2008), a escolha da estirpe para ser utilizada no teste pode variar entre os laboratórios, a maioria utiliza BVDV-la Singer ou NADL (FULTON et al., 1997), porém, não há consenso sobre a estirpe padrão de referência a ser utilizada (RIDPATH, 1994). De acordo com a OIE (2008), não existe estirpe ideal e na prática poderia ser selecionado um vírus que detecte maior número de reações sorológicas na população bovina local.

A seleção das estirpes utilizadas neste trabalho foi fundamentada pelos estudos realizados nos últimos 10 anos, por pesquisadores do Laboratório de Viroses de Bovídeos, Instituto Biológico em São Paulo (LVB-IB). Diversas estirpes foram caracterizadas pela técnica de Imunoperoxidase Indireta (IPX) utilizando diferentes anticorpos monoclonais e dentre estas, as amostras BVDV-1 IBSP11 e BVDV-2 IBSP-1020 reagiram com a maioria dos monoclonais testados, demonstrando amplo espectro de reação. Além disso, a citopatogenicidade foi outro fator determinante para a escolha dos isolados, pois facilita a leitura da reação de VN e manutenção das estirpes na rotina do laboratório. Estas amostras foram então selecionadas como representantes de isolados nacionais para comparação do título de anticorpos neutralizantes pela técnica de VN.

Mais de 50 isolados brasileiros do vírus foram caracterizados genética e/ou antigenicamente, e outros aguardam caracterização (FLORES et al., 2005). Ainda não há descrição sobre a qual subgenótipo pertencem os isolados nacionais utilizados neste trabalho, porém estudos em andamento visam obter mais informações sobre essas estirpes isoladas em território nacional.

Quando avaliados os resultados das estirpes individualmente, o isolado nacional do genótipo 2, IBSP-1020 teve o melhor desempenho, visto que detectou o maior número de reagentes nos animais estudados em MG (68,60\%), MS 
$(97,39 \%)$ e no total $(68,67 \%)$, enquanto que em SP as estirpes que obtiveram mais reagentes $(39,21 \%)$ foram NADL e IBSP-11, ambas do genótipo 1. Estes dados sugerem que, na população estudada circulam estirpes dos dois genótipos, indicando a necessidade de utilizar BVDV tipo 1 e 2 nos levantamentos sorológicos pela VN, prática esta, recomendada pela OIE (2008). Outros estudos relatam diferenças antigênicas entre os genótipos de BVDV, observadas pela neutralização cruzada (CORTESE, et al., 1998b; ELLIS et al., 2001; FULTON et al., 2003a, 2003b; MAKOSCHEY et al., 2001; HAMERS et al., 2003).

A inclusão de quatro estirpes sendo BVDV-1 (isolado americano NADL e isolado nacional IBSP-11) e BVDV-2 (isolado americano VS-253 e isolado nacional IBSP-1020) nas reações de VN revelou maior sensibilidade na detecção de anticorpos. Estes resultados sugerem que aumentando o número de estirpes na VN, detecta-se mais animais, porém, não houve diferença $(p=0,500)$ quando três ou duas estirpes foram utilizadas, indicando que mais relevante do que o aumento no número, é a escolha da estirpe, e seu genótipo. Ridpath (2003) estudou as diferenças entre os genótipos e subgenótipos do vírus e observou implicação no diagnóstico, devido à diversidade do BVDV.

O valor de detecção encontrado nos animais de MG e MS, quando as estirpes NADL e IBSP-1020 foram utilizadas, não foi estatisticamente diferente do encontrado com as quatro estirpes. Mais uma vez, reforça a necessidade de estirpes de ambos os genótipos no diagnóstico pela VN.

Além da diferença entre os genótipos, diferenças antigênicas ocorrem também entre isolados do mesmo genótipo. Fulton et al. (1997) observou diferença nos títulos de anticorpos neutralizantes dependendo do genótipo utilizado como desafio. Além disso, animais que receberam vacina contendo BVDV-1a produziram títulos de anticorpos mais baixos contra BVDV-1b do que contra o genótipo 1a (FULTON et al. 2003b). Em trabalho realizado por Vogel et al. (2002), os títulos neutralizantes frente isolado do BVDV-1 foram diferentes dos títulos contra vírus do mesmo genótipo, esses resultados reforçam que, há diferenças entre os vírus do mesmo genótipo. No Brasil dez isolados nacionais foram tipificados como sendo: quatro BVDV-1a, duas BVDV-1b, um BVDV-1d e três BVDV-2 (VILCEK et al., 2004). A diversidade antigênica citada pelo vírus da BVD parece ser um fator importante para o diagnóstico. 
Avaliando os resultados de neutralização cruzada, verificou-se que dos 1099 $(73,27 \%)$ (Tabela 1) sororreagentes a pelo menos um dos quatro vírus, somente $864(57,60 \%)$ foram reagentes aos quatro simultaneamente (Tabela 2), ou seja, estes animais produziram anticorpos que reagiram com todas as estirpes em questão. Contudo, pouco mais de $15 \%$ dos animais reagentes não apresentaram reatividade cruzada para as quatro estirpes utilizadas, esses resultados demonstraram presença de anticorpos neutralizantes reagentes aos diferentes vírus, independente do genótipo ou do local de origem da estirpe. E sugere a atividade de neutralização cruzada, mas sem que possa esquecer a ocorrência de infecções mistas. Por ser um estudo com infecção natural não há controle sobre o vírus que o animal entrou em contato, e não há impedimento que tenha entrado em contato com diferentes estirpes de BVDV.

Sabe-se que há diversidade antigênica entre as estirpes de BVDV (BOLIN; RIDPATH, 1989; RIDPATH et al., 1994; REDDY et al., 1995) e alguns isolados demonstram baixa reatividade sorológica cruzada com NADL (BOTTON et al., 1998). Jordão (2006) observou baixa reatividade cruzada entre NADL e IBSP-11 em estudo realizado com cobaias vacinadas com as estirpes citadas. Estes resultados devem ser interpretados com cautela, pois foram obtidos em animais de laboratório e não na espécie alvo.

Neste trabalho o título de anticorpos variou de 10, limiar de detecção da prova, a 5120, a maior parte dos animais apresentou título de anticorpos entre 40 e 160 para as quatro estirpes. Em SP, os títulos encontrados foram mais baixos com relação aos animais dos outros estados e do total.

De maneira geral, exceto nos animais de SP, os títulos frente ao IBSP-1020 foram mais altos, com predomínio nos animais do MS. Os dados encontrados podem indicar que o isolado nacional do BVDV-2 utilizado na VN é mais semelhante ao BVDV circulante nestes rebanhos. Em um estudo realizado com animais da região de Viçosa, títulos mais altos foram encontrados frente BVDV-2 VS-253 (isolado americano) em comparação com a estirpe BVDV-1 Singer, (NOGUEIRA, 2003).

A resposta imune individual é um dos fatores que pode influenciar o título de anticorpos, há animais que naturalmente respondem melhor. Além disso, devido à especificidade do teste, é essencial o uso, na VN, de um vírus antigenicamente similar ao vírus de campo da população testada (SANDVIK, 1999). 
Os altos títulos de anticorpos neutralizantes previnem o desenvolvimento da doença com vírus homólogo. Entretanto, muitos animais com anticorpos podem simultaneamente apresentar viremia por outras estirpes do vírus, fato observado em animais vacinados que após desafio apresentaram viremia transitória (POTGIETER, 1995; NOBIRON, et al., 2003).

Estudos de neutralização cruzada com soro de bovinos vacinados com vacina viva modificada (MLV) (CORTESE et al., 1998c; HAMERS et al., 2002) ou com a vacina inativada (HAMERS et al., 2002) demonstraram ampla neutralização cruzada contra 12 a 22 estirpes de BVDV. Entretanto, estes dados não correlacionam com os estudos de campo que não mostraram esta extensa neutralização cruzada (JONES et al., 2001; FULTON et al., 2003a).

Nos testes de VN cruzada com amostras brasileiras, diferenças de até 32 vezes nos títulos foram observadas quando algumas amostras de soro foram testadas frente a isolados de BVDV-1 e BVDV-2. Estudos anteriores demonstraram que títulos neutralizantes de 3200 contra uma determinada amostra podem falhar em neutralizar amostras antigenicamente diferentes em diluições de 1:10 (BOTTON et al., 1998). Em geral, a reatividade cruzada encontrada por Vogel et al. (2002) foi superior frente estirpes de BVDV-1, diferenças de até 32 vezes puderam ser observadas quando o soro de determinados animais foi testado frente a diferentes isolados.

A avaliação da diferença nos títulos de anticorpos de cada animal frente aos quatro vírus foi realizada pelo teste de Wilcoxon com correção de Bonferroni (diferença significante quando $p<0,008$ ) (Tabela 7). A comparação foi feita com os vírus dois a dois e os dados indicaram que, na maioria das situações houve diferença significante, indicando que a estirpe utilizada na VN é importante não só com relação ao valor de detecção, mas também na mensuração dos títulos de anticorpos frente cada estirpe do vírus. Diversos trabalhos demonstraram que os títulos de anticorpos são maiores frente estirpes homólogas utilizadas na VN, isto é, em animais experimentalmente infectados, ou vacinados com estirpe viral conhecida, quando a VN é realizada com o mesmo vírus os títulos são mais altos em comparação ao uso de estirpes diferentes para o diagnóstico (JONES et al., 2001; VOGEL et al., 2002; FULTON, et al., 2003a).

Vale ressaltar que a BVD, mesmo não causando sintomas evidentes em grande parte dos casos, pode causar prejuízos econômicos aos pecuaristas, as 
maiores perdas parecem resultar da infecção de fêmeas prenhes, pois interfere na produção, reprodução e desenvolvimento dos animais. E com a finalidade de entender melhor a dinâmica da infecção dos nossos rebanhos, juntamente com o conhecimento das estirpes virais circulantes, o diagnóstico deve ser realizado, observando as diferenças na metodologia empregada, origem e manejo dos animais a serem testados. 


\section{CONCLUSÕES}

Houve alta frequência de ocorrência de bovinos com anticorpos neutralizantes contra BVDV-1 (NADL e IBSP-11) e BVDV-2 (VS-253 e IBSP-1020), nas populações estudadas dos Estados de Minas Gerais, Mato Grosso do Sul e São Paulo. Foi observada variação na frequência de ocorrência de bovinos sororreagentes de acordo a procedência, com o sistema de criação e manejo do rebanho.

A estirpe BVDV-2 IBSP-1020, foi a que resultou em maior detecção de animais reagentes, e títulos mais altos de anticorpos, quando comparada com cada uma das outras estirpes.

O uso de mais de uma estirpe de BVDV, independente do genótipo ou origem do isolado, aumentou a sensibilidade de detecção de animais reagentes no teste de VN.

Neutralização cruzada foi observada entre todas as estirpes estudadas. Independente da origem do isolado e seu genótipo, a estirpe utilizada na VN influenciou no título de anticorpos evidenciando resposta cruzada, porém não descartando a possibilidade de infecção mista.

É importante selecionar estirpes representativas das amostras de campo, preferencialmente de ambos os genótipos, das regiões a serem estudadas para inclusão na VN, visando aumentar a sensibilidade do diagnóstico. 


\section{REFERÊNCIAS}

ADLER, H.; FRECH, B.; MEIER, P.; JUNGI, T. W.; PETERHANS, E. Noncytopathic strains of bovine viral diarrhea virus prime bovine bone marrow-derived macrophages for enhanced generation of nitric oxide. Biochemical and Biophysical Research Communications, United States, v. 202, n. 3, p.15621568, Aug.1994.

AMES, T. R. Hosts. In: GOYAL, S. M.; RIDPATH, J. F. Bovine viral diarrhea virus: diagnosis, management, and control. Ames, lowa: Blackwell Publishing, 2005. p. 171-175.

BAKER, J. A.; YORK, C. J.; GILLEPSIE, J. H.; MITCHELL, G. B. Virus diarrhea in cattle. American Journal of Veterinary Research, United States, v. 15, n. 57, p. 525-531, Oct. 1954.

BAKER, J. C. The clinical manifestations of bovine viral diarrhea infection. The Veterinary Clinics of North America. Food Animal Practice, United States, v. 11, n. 3, p. 425-445, Nov. 1995.

BENDFELDT, S.; GRUMMER, B.; GREISER-WILKE, I. No caspase activation but overexpression of Bcl-2 in bovine cells infected with noncytopathic bovine virus diarrhoea vírus. Veterinary Microbiology, Netherlands, v. 96, n. 4, p. 313-326, Nov. 2003.

BIELEFELDT OHMANN, $\mathrm{H}$. In situ characterization of mononuclear leukocytes in skin and digestive tract of persistently bovine viral diarrhea virus-infected clinically healthy calves and calves with mucosal disease. Veterinary Pathology, United States, v. 25, n. 4, p. 304-309, Jul. 1988.

BIELEFELDT OHMANN, $\mathrm{H}$. The pathologies of bovine viral diarrhea virus infection: a window on the pathogenesis. Veterinary Clinics North America: Food Animal Practice, United States, v. 11, n. 3, p. 447-476, Nov. 1995.

BOLIN, S. R. Bovine viral diarrhea viruses in mixed infections. In: BROGDEN, K. M.; GUTHMILLER, J. M. Polymicrobial Diseases. Washington DC: ASM Press, 2002. p. 33-50.

BOLIN, S. R. Immunogens of bovine viral diarrhea virus. Veterinary microbiology, Netherlands, v. 37, n. 3-4, p. 263-271, Nov.1993. 
BOLIN, S. R. The current understanding about the pathogenesis and clinical forms of BVD. Veterinary Medicine. United States, v. 85, n. 10, p. 1123-1132, 1990.

BOLIN, S. R.; RIDPATH, J. F. Assessment of protection from systemic infection or disease afforded by low to intermediate titers of passively acquired neutralizing antibody against bovine viral diarrhea virus in calves. American Journal of Veterinary Research, United States, v. 56, n. 6, p. 755-759, Jun. 1995.

BOLIN, S. R.; RIDPATH, J. F. Differences in virulence between two noncytopathic bovine viral diarrhea viruses in calves. American Journal of Veterinary Research, United States, v. 53, n. 11, p. 2157-2163, Nov. 1992.

BOLIN, S. R.; RIDPATH, J. F. Prevalence of bovine viral diarrhea virus genotypes and antibody against those viral genotypes in fetal bovine serum. Journal of Veterinary Diagnostic Investigation. United States, v. 10, n. 2, p.135-139, Apr. 1998.

BOLIN, S. R.; RIDPATH, J. F. Range of viral neutralizing activity and molecular specificity of antibodies induced in cattle by inactivated bovine viral diarrhea virus vaccines. American Journal of Veterinary Research, United States, v. 51, n. 5, p. 703-707, May 1990.

BOLIN, S. R.; RIDPATH, J. F. Specificity of neutralizing and precipitating antibodies induced in healthy calves by monovalent modified-live bovine viral diarrhea virus vaccines. American Journal of Veterinary Research, United States, v. 50, n. 6, p. 817-821, Jun. 1989.

BOLIN, S. R.; RIDPATH, J. F. The clinical significance of genetic variation among bovine viral diarrhea viruses. Veterinary Medicine, United States, v. 91, n. 10, p. 958-961, 1996.

BOTTON, S. A.; SILVA, A. M.; BRUM, M. C. S.; WEIBLEN, R.; FLORES, E. F. Antigenic characterization of Brazilian isolates of bovine viral diarrhea virus (BVDV) with monoclonal antibodies and by crossneutralization. Brazilian Journal Medical Biological Research, Brazil, v. 31, p.1429-1438, Nov. 1998.

BRITO, W. M. E. D.; SOUZA, W. J.; VIEIRA, S.; LINHARES, D. C. L.; BARBOSA, A. C. V. C.; ALFAIA, B. T. Serological study on bovine viral diarrhea in non vaccinated dairy herds with reproductive disorders from Goiás. Virus Reviews and Research, Rio de Janeiro, v. 7, n. 1, p. 144, 2002. 
BROCK, K. V. Diagnosis of bovine viral diarrhea virus infections. The Veterinary Clinics of North America. Food Animal Practice, United States, v. 11, n. 3, p. 549-561, Nov. 1995.

BROCK, K. V. The persistence of bovine viral diarrhea virus. Biologicals, England, v. 31, n. 2, p. 133-135, Jun. 2003.

BROWN, F. The development of chemically synthesized vaccines. Advances in Veterinary Science and Comparative Medicine. United States, v. 33, p. 173-193, 1989.

BROWNLIE, J. The pathogenesis of bovine viral diarrhoea virus infections. Revue Scientifique et Technique (Office International des Epizooties), France, v. 9, n. 1, p. 43-59, Mar. 1990.

BROWNLIE, J.; CLARKE, M. C.; HOWARD, C. J. Clinical and experimental mucosal disease - defining a hypothesis for pathogenesis. In: HARKNESS, J. W. (Ed.). Pestivirus Infections of Ruminants. Brussels: CEC, 1985. p. 147-156. A seminar in the CEC Program of Coordination of Research on Animal Husbandry, Brussels, 10-11 September, 1985.

BROWNLIE, J.; CLARKE, M. C.; HOWARD, C. J. Experimental infection of cattle in early pregnancy with a cytopathic strain of bovine virus diarrhea virus. Research in Veterinary Science, England, v. 46, p. 307-311, May 1989.

BROWNLIE, J. M.; CLARKE, M. C.; HOWARD, C. J.; POCOCK, D. H. Pathogenesis and epidemiology of bovine virus diarrhoea virus infection in cattle. Annales de Recherches Vétérinaires, France, v. 18, n. 2, p. 157-166, 1987.

CANAL, C. W.; STRASSER, M.; HERTIG, C.; MASUDA, A.; PETERHANS, E. Detection of antibodies to bovine viral diarrhoea virus (BVDV) and characterization of genomes of BVDV from Brazil. Veterinary Microbiology, Netherlands, v. 63, p. 85-97, Oct. 1998.

CASTRUCCI, G.; FRIGERI, F.; FERRARI, M.; TRALDI, V. The vaccination and challenge with bovine viral diarrhea virus (BVDV) of calves previously infected with a non-cytopathic BVDV. Comparative Immunology, Microbiology and Infectious Diseases, England, v. 14, n. 1, p. 31-38, 1991.

CHASE, C. C.; BRAUN, L. J.; LESLIE-STEEN, P.; GRAHAM, T.; MISKIMINS, D.; RIDPATH, J. F. Bovine viral diarrhea virus multiorgan infection in two white-tailed 
deer in southeastern South Dakota. Journal of Wildlife Diseases, United States, v. 44, n. 3, p. 753-759, Jul. 2008.

CHASE, C. C.; CHASE, S. K.; FAWCETT, L. Trends in the BVDV serological response in the Upper Midwest. Biologicals. England, v. 31, n. 2, p. 145-151, Jun. 2003.

CHASE, C. C.; ELMOWALID, G.; YOUSIF, A. A. The immune response to bovine viral diarrhea virus: a constantly changing picture. The Veterinary Clinics of North America. Food Animal Practice, United States, v. 20, n. 1, p. 95-114, Mar. 2004.

CHILDS, T. X. Disease in cattle - Saskatchewan. Canadian Journal of Comparative Medicine, Canada, v. 10, p. 316-319, Nov. 1946.

COOK, L. G.; LITTLEJOHNS, I. R.; JESSEP, T. M. Induced sero-conversion in heifers with a field strain of bovine pestivirus - a comparison of methods and doses. Australian Veterinary Journal, Australia, v. 67, n. 11, p. 393-395, Nov. 1990.

CORAPI, W. V.; DONIS, R. O.; DUBOVI, E. J. Characterization of a panel of monoclonal antibodies and their use in the study of the antigenic diversity of bovine viral diarrhea virus. American Journal of Veterinary Research, United States, v. 51, n. 9, p. 1388-1394. Sep. 1990.

CORAPI, W. V.; DONIS, R. O.; DUBOVI, E. J. Monoclonal antibody analyses of cytopathic and noncytopathic viruses from fatal bovine viral diarrhea virus infections. Journal of Virology, United States, v. 62, n. 8, p. 2823-2827, Aug. 1988.

CORAPI, W. V.; ELLIOTT, R. D.; FRENCH, T. W.; ARTHUR, D. G.; BEZEK, D. M.; DUBOVI, E. J. Thrombocytopenia and hemorrhages in veal calves infected with bovine viral diarrhea virus. Journal of the American Veterinary Medical Association, United States, v. 196, n. 4, p. 590-596, Feb. 1990.

CORAPI, W. V.; FRENCH, T. W.; DUBOVI, E. J. Severe thrombocytopenia in young calves experimentally infected with noncytopathic bovine viral diarrhea virus. Journal of Virology, United States, v. 63, n. 9, p. 3934-3943. Sep. 1989.

CORREA, W. M.; NETTO, Z. C.; BARROS, H. M. Nota clínico-patológica de uma enfermidade das mucosas em São Paulo. Arquivos do Instituto Biológico, São Paulo, v. 35, p. 141-151, 1968. 
CORTEZ, A.; HEINEMANN, M. B.; CASTRO, A. M. M. G.; SOARES, R. M.; PINTO, A. M. V.; ALFIERI, A. A.; FLORES, E. F.; LEITE, R. C.; RICHTZENHAIN, L. J. Genetic characterization of Brazilian bovine viral diarrhea virus isolates by partial nucleotide sequencing of the 5'-UTR region. Pesquisa Veterinária Brasileira, Rio de Janeiro, v. 26, n. 4, p. 211-216, 2005.

CORTESE, V. S.; GROOMS, D. L.; ELLIS, J.; BOLIN, S. R.; RIDPATH, J. F.; $\mathrm{BROCK}, \mathrm{K}$. V. Protection of pregnant cattle and their fetuses against infection with bovine viral diarrhea virus type 1 by use of a modified-live virus vaccine. American Journal of Veterinary Research, United States, v. 59, n. 11, p. 1409-1413, Nov. 1998a.

CORTESE, V. S.; WEST, K. H.; HASSARD, L. E.; CARMANS, S.; ELLIS, J. A. Clinical and immunologic responses of vaccinated and unvaccinated calves to infection with a virulent type II isolate of bovine viral diarrhea virus. Journal of the American Veterinary Medical Association, United States, v. 213, n. 9, p. 13121319, Nov. 1998b.

CORTESE, V. S.; WHITTAKER, R.; ELLIS, J.; RIDPATH, J. F.; BOLIN, S. R. Specificity and duration of neutralizing antibodies induced in healthy cattle after administration of a modified-live virus vaccine against bovine viral diarrhea.

American Journal of Veterinary Research, United States, v. 59, p. 848-850, Jul. 1998c.

COUVREUR, B.; LETELLIER, C.; COLLARD, A.; QUENON, P.; DEHAN, P.; HAMERS, C.; PASTORET, P. P.; KERKHOFS, P. Genetic and antigenic variability in bovine viral diarrhea virus (BVDV) isolates from Belgium. Virus Research, Netherlands, v. 85, p. 17-28, Apr. 2002.

DAHLE, J.; LIESS, B. A review on classical swine fever infections in pigs: epizootiology, clinical disease and pathology. Comparative Immunology, Microbiology and Infectious Diseases, England, v. 15, n. 3, p. 203-211, Jul. 1992.

DENG, R.; BROCK, K. V. 5' and 3' untranslated regions of pestivirus genome: primary and secondary structure analyses. Nucleic Acids Research, England, v. 21, n. 8, p. 1949-1957, Apr. 1993.

DIAS, F. C. Vírus da diarréia viral bovina (BVDV): caracterização epidemiológica e molecular nos estados de Minas Gerais e São Paulo, Brasil. 2008. 157 f. Tese (Doutorado em Medicina Veterinária) - Faculdade de Ciências Agrárias e Veterinárias de Jaboticabal, Universidade Estadual Paulista - Campus Jaboticabal, Jaboticabal, 2008. 
DIAS, F. C.; SAMARA, S. I. Detecção de anticorpos contra o vírus da diarréia viral bovina no soro sangüíneo, no leite individual e no leite de conjunto em tanque de expansão de rebanhos não vacinados. Brazilian Journal of Veterinary Research and Animal Science, São Paulo, v. 40, n. 3, p. 161-168, Mai. 2003.

DONIS, R. O. Bovine viral diarrhea: the unraveling of a complex of clinical manifestations. The Bovine Proceedings, [S.I], v. 20, p. 16-22, 1989.

DONIS, R. O. Molecular biology of bovine viral diarrhea virus and its interactions with the host. The Veterinary Clinics of North America: Food Animal Practice. United States, v. 11, n. 3, p. 393-423, Nov. 1995.

DONIS, R. O.; CORAPI, W.; DUBOVI, E. J. Neutralizing monoclonal antibodies to bovine viral diarrhoea virus bind to the $56 \mathrm{~K}$ to $58 \mathrm{~K}$ glycoprotein. The Journal of general virology, England, v. 69, pt 1, p. 77-86, Jan. 1988.

DONIS, R.; DUBOVI, E. J. Differences in virus-induced polypeptides in cells infected by cytopathic and noncytopathic biotypes of bovine virus diarrhea-mucosal disease virus. Virology, United States, v. 158, n. 1, p. 168-173, May 1987.

DRISKELL, E. A.; RIDPATH, J. F. A survey of bovine viral diarrhea virus testing in diagnostic laboratories in the United States from 2004 to 2005. Journal of veterinary diagnostic investigation. United States, v. 18, n. 6, p. 600-605, Nov. 2006.

DUBOVI, E. J. Genetic diversity and BVD virus. Comparative Immunology Microbiology and Infectious Diseases, England, v. 15, n. 3, p. 155-162, Jul. 1992.

DUFFELL, S. J.; HARKNESS, J. W. Bovine virus diarrhoea-mucosal disease infection in cattle. Veterinary Record, England, v. 117, n. 10, p. 240-245, Sep. 1985.

EDWARDS, S. The diagnosis of bovine virus diarrhoea-mucosal disease in cattle. Revue Scientifique et Technique (International Office of Epizootics). France, v. 9, n. 1, p. 95-103, Mar. 1990.

EDWARDS, S.; PATON, D. Antigenic differences among pestiviruses. Veterinary Clinics North America: Food Animal Practice, United States, v.11, p. 563-577, Nov. 1995. 
ELLIS, J.; WEST, K.; CORTESE, V.; KONOBY, C.; WEIGEL, D. Effect of maternal antibodies on induction and persistence of vaccine-induced immune responses against bovine viral diarrhea virus type II in young calves. Journal of the American Veterinary Medical Association, United States, v. 219, n. 3, p.351-356, Aug. 2001.

FAUQUET, C. M.; MAYO, M. A., MANILOFF, J.; DESSELBERGER, U.; BALL, L. A. (Ed.) Virus taxonomy. In: REPORT OF THE INTERNATIONAL COMMITTEE ON TAXONOMY OF VIRUSES, 8., 2005, London: Elsevier Academic Press; 2005, $1162 p$.

FIGUEIREDO, H. C. P.; VIEIRA, P. R.; LAGE, A. P.; LEITE, R. C. Prevalência de anticorpos contra o vírus da Diarréia Viral Bovina a vírus em Minas Gerais, Brasil. Revista Brasileira de Reprodução Animal, Belo Horizonte, v. 21, p. 11-15, 1997.

FLORES, E. F.; GIL, L. H. V. G.; BOTTON, S. A.; WEIBLEN, R.; RIDPATH, J. F.; KREUT, L. C.; PILATI, C.; DRIEMEYER, D.; MOOJEN, V.; WENDELSTEIN, A. C. Clinical, pathological and antigenic aspects of bovine viral diarrhea virus (BVDV) type 2 isolates identified in Brazil. Veterinary Microbiology, Netherlands v.77, n. 12, p. 175-183, Nov. 2000a.

FLORES, E. F.; RIDPATH, J.; WEIBLEN, R.; VOGEL, F. S. F.; GIL, L. H. V. G. Phylogenetic analysis of Brazilian bovine viral diarrhea virus type 2 (BVDV-2) isolates: evidence for a subgenotype within BVDV-2. Virus Research, Netherlands, v. 87, n. 1, p. 51-60, Apr. 2002.

FLORES, E. F.; WEIBLEN, R.; GIL, L. H. V. G.; TOBIAS, F. L.; LIMA, M.; GARCEZ, D. C.; BOTTON, S. A. Diversidade antigênica de amostras do vírus da diarréia viral bovina isoladas no Brasil: implicações para o diagnóstico e estratégias de imunização. Arquivo Brasileiro de Medicina Veterinária e Zootecnia, Belo Horizonte, v. 52, n. 1, p.11-17, Fev. 2000b.

FLORES, E. F.; WEIBLEN, R.; VOGEL, F. S. F.; ROEHE, P. M.; ALFIERI, A. A.; PITUCO, E. M. A infecção pelo vírus da Diarréia Viral Bovina (BVDV) no Brasil histórico, situação atual e perspectivas. Pesquisa Veterinária Brasileira, Rio de Janeiro, v. 25, n.3, p.125-134, Jul. 2005.

FRANCKI, R.; FAUQUET, C.; KNUDSON, D.; BROWN, F. Classification and nomenclature of viruses. Fifth Report of the International Committee on Taxonomy of Viruses (ICTV). Archives of Virology, New York, v. 2, p. 223-427, 1991. 
bovine virus diarrhoea virus. Veterinary Record, England, v. 144, n. 5, p. 111-114, Jan. 1999.

FREY, H. R.; FLEBBE, U.; LIESS, B. Prevalence and clinical symptoms of persistent BVD-virus infection in cattle herds of Lower Saxony. Der Praktische Tierarzt, Germany, v. 77, n. 1, p. 49-52. 1996

FULTON, R. W.; CONFER, A. W.; BURGE, L. J.; PERINO, L. J.; D'OFFAY, J. M.; PAYTON, M. E.; MOCK, R. E. Antibody responses by cattle after vaccination with commercial viral vaccines containing bovine herpesvirus-1, bovine viral diarrhea virus, parainfluenza-3 virus, and bovine respiratory syncytial virus immunogens and subsequent revaccination at day 140 . Vaccine, Netherlands, v. 13, n. 8, p. 725-733, 1995.

FULTON, R. W.; HESSMAN, B.; JOHNSON, B. J.; RIDPATH, J. F.; SALIKI, J. T.; BURGE, L. J.; SJEKLOCHA, D.; CONFER, A. W.; FUNK, R. A.; PAYTON, M. E. Evaluation of diagnostic tests used for detection of bovine viral diarrhea virus and prevalence of subtypes $1 \mathrm{a}, 1 \mathrm{~b}$, and $2 \mathrm{a}$ in persistently infected cattle entering a feedlot. Journal of the American Veterinary Medical Association. United States v. 228, n. 4, p. 578-584, Feb. 2006.

FULTON, R. W.; RIDPATH, J. F.; CONFER, A. W.; SALIKI, J. T.; BURGE, J. L.; PAYTON, M. E. Bovine viral diarrhoea virus antigenic diversity: impact on disease and vaccination programs. Biologicals, London, v. 31, n. 2, p. 89-95, Jun. $2003 a$.

FULTON, R. W.; RIDPATH, J. F.; ORE, S.; CONFER, A. W.; SALIKI, J. T.; BURGE, J. L.; PAYTON, M. E. Bovine viral diarrhoea virus (BVDV) subgenotypes in diagnostic laboratory accessions: Distribution of BVDV1a, 1b, and 2a subgenotypes. Veterinary Microbiology, Netherlands, v. 111, n. 1-2, p. 35-40, Nov. 2005.

FULTON, R. W.; SALIKI, J. T.; BURGE, L. J.; d'OFFAY, J. M.; BOLIN, S. R.; MAES, R. K.; BAKER, J. C.; FREY, M. L. Neutralizing Antibodies to Type 1 and 2 Bovine Viral Diarrhea Viruses: Detection by Inhibition of Viral Cytopathology and Infectivity by Immunoperoxidase Assay. Clinical Diagnostic Laboratory Immunology, Netherlands, v. 4, n. 3, p. 380-383, May 1997.

FULTON, R. W.; STEP, D. L.; RIDPATH, J. F.; SALIKI, J. T.; CONFER, A. W.; JOHNSON, B. J.; BRIGGS, R. E.; HAWLEY, R. V.; BURGE, L. J.; PAYTON, M. $E$. Response of calves persistently infected with noncytopathic bovine viral diarrhea virus (BVDV) subtype $1 \mathrm{~b}$ after vaccination with heterologous BVDV strains in modified live virus vaccines and mannheimia haemolytica bacterin-toxoid. Vaccine, Netherlands, v. 21, n. 21-22, p. 2980-2985, Jun. 2003b. 
GIL, L. H. V. G. Seqüenciamento, análise filogenética e caracterização de polipeptídeos não-estruturais de amostras do vírus da Diarréia Viral Bovina (BVDV). 1998. 69 f. Tese (Mestrado) - Universidade Federal de Santa Maria, Santa Maria. 1998.

GILLESPIE, J. H.; BAKER, J. A.; McENTEE, K. A cytopathogenic strain of virus diarrhea virus. Cornell Veterinarian, United States, v. 50, p. 73-79, Jan. 1960.

GREISER-WILKE, I.; GRUMMER, B.; MOENNIG, V. Bovine viral diarrhoea eradication and control programmes in Europe. Biologicals, London, v. 31, n. 2, p. 113-118, Jun. 2003.

GROOMS, D. L.; BOLIN, S. R.; COE, P. H.; BORGES, R. J.; COUTU, C. E. Fetal protection against exposure to bovine viral diarrhea virus following administration of a vaccine containing an inactivated bovine viral diarrhea virus fraction to cattle.

American Journal of Veterinary Research, United States, v. 68, n. 12, p. 14171422, Dec. 2007.

GRUMMER, B.; BENDFELDT, S.; GREISER-WILKE, I. Apoptosis inhibitors delay the cytopathic effect of bovine viral diarrhoea virus (BVDV). Journal of Veterinary Medicine, Germany, v. 49, p. 298-303, Aug. 2002.

HAMERS, C.; COUVREUR, B.; DEHAN, P.; LETELLIER, C.; FISCHER, L.; BRUN, A. J.; LEWALLE, P.; MICHAUX, C.; KERKHOFS, P.; PASTORET, P. P. Assessment of the clinical and virological protection provided by a commercial inactivated bovine viral diarrhoea virus genotype 1 vaccine against a BVDV genotype 2 challenge. The Veterinary Record, England, v. 153, n. 8, p. 236-240, Aug. 2003.

HAMERS, C.; DI VALENTIN, E.; LECOMTE, C.; LAMBOT, M.; JORISY, E.; GENICOTY, B.; PASTORET, P. P. Virus Neutralising Antibodies Against 22 Bovine Viral Diarrhoea Virus Isolates in Vaccinated Calves. The Veterinary Journal, England, v. 163, p. 61-67, Jan. 2002.

HEINZ, F. X.; COLLETT, M. S.; PURCELL, R. H.; GOULD, E. A.; HOWARD, C. R.; HOUGHTON, M.; MOORMANN, R. J.; RICE, C. M.; THIEL, H. J. 2000. Genus pestivirus. In: VAN REGENMORTEL, M. H.; FOUQUET, C. M.; BISHOP, D. H. L.; CARSTENS, E. B.; ESTES, M. K.; LEMON, S. M.; MANILOFF, J.; MAYO, M. A.; McGEOCH, D. J.; PRINGLE, C. R.; WICKNER, R. B. (Ed.). Virus taxonomy classification and nomenclature of viruses. In: REPORT OF THE INTERNATIONAL COMMITTEE ON TAXONOMY OF VIRUSES, 7., 2000, San Diego: Academic Press, 2000. p. 867-872. 
HOUE, H. Age distribution of animals persistently infected with bovine vírus diarrhea virus in twenty-two danish dairy herds. Canadian journal of veterinary research, Canada, v. 56, n. 3, p. 194-198, Jul. 1992.

HOUE, H. Economic impact of BVDV infection in dairies. Biologicals, London, v. 31, n. 2, p. 137-143, Jun. 2003.

HOUE, H. Epidemiological features and economical importance of bovine virus diarrhea virus (BVDV) infections. Veterinary Microbiology, Netherlands, v. 64, n. 2-3, p. 89-107, Jan. 1999.

HOUE, H. Survivorship of animals persistently infected with bovine virus diarrhoea virus (BVDV). Preventive Veterinary Medicine, Netherlands, v. 15, n. 4, p. 275283, Mar. 1993.

HOUE, H.; MEYLING, A. Prevalence of bovine virus diarrhoea (BVD) in 19 Danish dairy herds and estimation of incidence or infection in early pregnancy. Preventive Veterinary Medicine, Netherlands, v. 11 p. 9-16, Apr. 1991.

HOWARD, C. J. Immunological responses to bovine virus diarrhoea virus infections. Revue Scientifique et Technique (International Office of Epizootics). France, v. 9, n. 1, p. 95-103, Mar. 1990.

HULT, L.; LINDBERG, A. Experiences from BVDV control in Sweden. Preventive Veterinary Medicine, Netherlands, v. 72, p. 143-148, Nov. 2005

ICTVdB. The Universal Database of the International Committee on Taxonomy of Viruses. 00.026.0.02.001. Bovine viral diarrhea virus 1. 2008. Disponível em: <http://www.ncbi.nlm.nih.gov/ICTVdb>. Acesso em: 17 maio 2009.

JONES, L.; VAN CAMPEN, H.; XU, Z. C.; SCHNACKEL, J. A. Comparison of neutralizing antibodies to type $1 \mathrm{a}, 1 \mathrm{~b}$ and 2 bovine viral diarrhea virus from experimentally infected and vaccinated cattle. The Bovine Practitioner, [S.I.] v. 35, p. 137-140, 2001.

JORDÃO, R. S. Resposta sorológica de cobaias imunizadas com vacinas inativadas, oleosa e aquosa, contendo isolado brasileiro do Vírus da Diarréia Viral Bovina (BVDV) em comparação com vacina comercial. 2006. $60 \mathrm{f}$. Dissertação de Mestrado em Ciências (Microbiologia) - Instituto de Ciências Biomédicas, Universidade de São Paulo, São Paulo. 2006. 
KIM, I. J.; HYUN, B. H.; SHIN, J. H.; LEE, K. K.; LEE, K. W.; CHO, K. O.; KANG, M. L. Identification of Bovine Viral Diarrhea Virus type 2 in Korean native goat (Capra hircus). Virus Research, Netherlands v. 121, n. 1, p. 103-106, Oct. 2006.

KIRKLAND, P. D.; RICHARDS, S. G.; ROTHWELL, J. T.; STANLEY, D. F. Replication of bovine viral diarrhoea virus in the bovine reproductive tract and excretion of virus in semen during acute and chronic infections. The Veterinary Record, England, v. 128, n. 25, p. 587-590, Jun. 1991.

KRAHL, M.; BRABA, A. C.; OLIVEIRA, L. G.; NETO, J. A. S. P.; ROSA, J. C. A.; WUNDER JÚNIOR, E. Pesquisa de anticorpos para leptospirose, Rinotraqueíte Infecciosa Bovina e Diarréia Viral Bovina em soros bovinos de propriedades rurais do Rio Grande do Sul. In: CONGRESSO DE MEDICINA VETERINÀRIA, 25., 1997, Gramado. Anais... Gramado: Sociedade Brasileira de Virologia 1997, p. 174.

KRAMPS, J. A.; MAANEN, C. V.; WETERING, G. V.; STIENSTRA, G.; QUAK, S.; BRINKHOF, J.; RØNSHOLT, L.; NYLIN, B. A simple, rapid and reliable enzymelinked immunosorbent assay for the detection of bovine virus diarrhoea virus (BVDV) specific antibodies in cattle serum, plasma and bulk milk. Veterinary Microbiology, Netherlands, v. 64, n. 2-3, p. 135-144, Jan. 1999.

KUMMERER, B. M.; TAUTZ, N.; BECHER, P.; THIEL, H.; MEYERS, G. The Genetic basis for cytopathogenicity of pestiviruses. Veterinary Microbiology, Netherlands, v. 77, n. 1-2, p. 117-128, Nov.2000.

LANGONI, H.; PAES, A. C.; TONIN, F. B.; SILVA, A. V.; DENARDI, M. B. Prevalence of BVD, IBR and PI3 in bovine by ELISA test. In: VIROLOGIA, 5. 1995, Ribeirão Preto. Anais... Ribeirão Preto: Sociedade Brasileira de Virologia. 1995, N.B43.

LIEBLER-TENORIO, E. M.; RIDPATH, J. E.; NEILL, J. D. Distribution of viral antigen and development of lesions after experimental infection of calves with a BVDV 2 strain of low virulence. Journal of Veterinary Diagnostic Investigation, United States, v. 15, n. 3, p. 221-232. May 2003a.

LIEBLER-TENORIO, E. M.; RIDPATH, J. E.; NEILL, J. D. Distribution of viral antigen and development of lesions after experimental infection with highly virulent bovine viral diarrhea virus type 2 in calves. American Journal of Veterinary Research, United States, v. 63, n. 11, p. 1575-1584, Nov. 2002.

LIEBLER-TENORIO, E. M.; RIDPATH, J. E.; NEILL, J. D. Lesions and tissue distribution of viral antigen in severe acute versus subclinical acute infection with BVDV2. Biologicals, England, v. 31, n. 2, p. 119-122, Jun. $2003 \mathrm{~b}$. 
LIEBLER-TENORIO, E. M.; RIDPATH, J. E.; NEILL, J. D. Lesions Distribution of viral antigen and tissue lesions in persistent and acute infection with the homologous strain of noncytopathic bovine viral diarrhea virus. Journal of Veterinary Diagnostic Investigation, United States, v. 16, n. 5, p. 388-396, Sep. 2004.

LINDBERG, A. L. E. Bovine viral diarrhoea virus infections and its control: A review. Veterinary Quarterly, Netherlands, v. 25, n. 1, p. 2-16, Mar. 2003.

LINDBERG, A. L. E. Epidemiology and Eradication of Bovine Viral Diarrhoea Virus Infections. 2002. 55 f. Tese (Doutorado) - Swedish University of Agricultural Sciences, Uppsala, 2002.

LØKEN, T. Ruminant pestivirus infections in animals other than cattle and sheep. The Veterinary clinics of North America. Food animal practice, United States, v. 11, n. 3, p. 597-614, Nov. 1995.

LØKEN, T.; KROGSRUD, J.; LARSEN, I. L. Pestivirus infections in Norway. Serological investigations in cattle, shepp and pigs. Acta veterinaria Scandinavica, England, v. 32, n. 1. p. 27-34, 1991.

MAKOSCHEY, B.; JANSSEN, M. G.; VRIJENHOEK, M. P.; KORSTEN J. H.; MAREL, P. An inactivated bovine virus diarrhoea virus (BVDV) type 1 vaccine affords clinical protection against BVDV type 2. Vaccine, Netherlands, v. 19, n. 23/24, p. 3261-3268, Apr. 2001.

MELO, C. B.; OliveIRA, A. M.; FIGUEIREDO, H. C. P.; LEITE, R. C.; LOBATO, Z. I. P. Prevalência de anticorpos contra o herpesvirus bovino-1, vírus da diarréia viral bovina e vírus da leucose enzoótica bovina em bovinos do Estado do Sergipe, Brasil. Revista Brasileira de Reprodução Animal. Belo Horizonte, v. 21, n. 2, p. 160-161, 1997.

MEYERS, G.; RÜMENAPF, T.; TAUTZ, N.; DUBOVI, E. J.; THIEL, H. J. Insertion of cellular sequences in the genome of bovine viral diarrhea virus. Archives of virology. Supplementum. Austria, v. 3, p, 133-142, 1991.

MEYLING, A.; HOUE, H.; JENSEN, A. M. Epidemiology of bovine virus diarrhoea virus. Revue Scientifique et Technique, France, v. 9, n. 1, p. 75-93, Mar. 1990.

MÜLLER, T.; DEPNER, K. R.; BUROW, J.; AHL, R.; CONRATHS, F. J.; MOENNIG, $V$. Comparison of different BVD virus strains for their use in the differential 
diagnosis of classical swine fever--an attempt to standardize neutralization tests. DTW. Deutsche Tierärztliche Wochenschrift, Germany, v. 104, n. 3, p. 91-96, Mar. 1997.

MURPHY, F. A.; GIBBS, E. P. J.; HORZINEK, M. C.; STUDDERT, M. J.

Herpesviridae. In: Veterinary virology. 3 ed. San Diego: Academic Press, 1999. p. 322-323

NISKANEN, R. Relationship between the levels of antibodies to bovine viral diarrhoea virus in bulk tank milk and the prevalence of cows exposed to the virus. The Veterinary Record, England, v. 133, n. 14, p. 341-344, 1993.

NISKANEN, R.; LINDBERG, A.; LARSSON, B.; ALENIUS, S. Primarily BVDVinfected calves as transmitters of the infection. In: WORLD BUIATRICS CONGRESS, 19., 1996. Edinburgh. Proceedings, United Kingdom: British Cattle Veterinary Association, 1996. p. 593-594.

NOBIRON, I.; THOMPSON, I.; BROWNLIE, J.; COLLINS, M. E. DNA vaccination against bovine viral diarrhoea virus induces humoral and cellular responses in cattle with evidence for protection against viral challenge. Vaccine, Netherlands, v. 21, n. 17-18, p. 2082-2092, May. 2003.

NOGUEIRA, F. S. Diagnóstico da infecção pelo vírus da diarréia viral bovina em propriedades da microrregião de viçosa. 2003. 51 f. Dissertação (Mestrado) - Universidade Federal de Viçosa, Minas Gerais. 2003.

NORONHA, R. P.; CAMPOS, G. S.; SARDI, S. I. Pesquisa do vírus da diarréia viral bovina em bovinos jovens. Brazilian Journal of Veterinary Research and Animal Science, São Paulo, v. 40, p. 424-430, 2003.

OIE. OFFICE INTERNATIONAL DES EPIZOOTIES - World Organisation for Animal Health. Manual of Diagnostic Tests and Vaccines for Terrestrial Animals, 2008. Disponível em <http://www.oie.int/eng/normes/mmanual/2008/pdf/2.04.08_BVD.pdf>. Updated 17/07/08. Acesso em: 17 maio 2009.

OLIVEIRA, E. A. S. Caracterização antigênica de amostras de vírus da diarréia vírica bovina com anticorpos monoclonais. 1996. 65 f. Dissertação (Mestrado) Faculdade de Veterinária, Universidade Federal do Rio Grande do Sul, Porto Alegre. 1996.

PATON, D. J. Pestivirus diversity. Journal of comparative pathology, England v. 112, n. 3, p. 215-36. Apr. 1995. 
PELLEGRIN, A. O.; SERENO, J. R. B.; LEITE, R. C. Seropositivity to bovine viral diarrhoea virus (BVDV) and bovine herpesvirus type 1 (BHV-1) in Zebu cows in the Brazilian Pantanal. Arquivo Brasileiro de Medicina Veterinária e Zootecnia, Belo Horizonte, v. 49, n. 3, p. 375-377, Jun. 1997

PELLERIN, C.; VAN DEN HURK, J.; LECOMTE, J.; TUSSEN, P. Identification of a new group of bovine viral diarrhea virus strains associated with severe outbreaks and high mortalities. Virology, United States, v. 203, p. 260-268, Sep. 1994.

PETERHANS, E.; JUNGI, T. W.; SCHWEIZER, M. BVDV and innate immunity. Biologicals, England v. 31, n. 2, p. 107-112, Jun. 2003.

PITUCO, E. M.; DEL FAVA, C. 1998. Situação do BVDV na América do Sul. In: SIMPÓSIO INTERNACIONAL SOBRE HERPESVIRUS BOVINO (TIPO 1 E 5) E VÍRUS DA DIARRÉIA VIRAL BOVINA (BVDV), 1998, Santa Maria. Anais... Santa Maria, Rio Grande do Sul, 1998. p. 49-57.

POTGIETER, L. N. Immunology of bovine viral diarrhea virus. The Veterinary Clinics of North America. Food Animal Practice, United States, v. 11, n. 3, p. 501-520, Nov. 1995.

QUINCOZES, C. G.; FISCHER, G.; HÜBNER, S. O.; VARGAS, G. D.; VIDOR, T.; BROD, C. S. Prevalência e fatores associados à infecção pelo vírus da diarréia viral bovina na região Sul do Rio Grande do Sul. Semina: Ciências Agrárias, Londrina, v. 28, n. 2, p. 269-276, abr/jun. 2007.

REDDY, J. R.; XUE, W.; RIVERA, S.; MINOCHA, H. C. Antigenic differences between a field isolate and vaccine strains of bovine viral diarrhea virus. Journal of Clinical Microbiology, United States, v. 33, p. 2159-2161, Aug. 1995.

REED, L. J.; MUENCH, H. A simple method of estimating fifty per cent endpoints. The American Journal of Hygiene, v. 27, n. 3, p. 493-497, May, 1938.

RIBEIRO, M. B.; GALVÃO, C. L.; COSTA, A. R.; RODRIGUES, F. M.; SUZART, J. C. C. Infecções pelo vírus da rinotraqueíte infecciosa bovina/vulvovaginite pustular infecciosa, diarréia viral bovina e parainfluenza-3, detectadas por meio de avaliação sorológica no estado da Bahia. Boletim EPABA, Salvador, n. 11, 1987.

RICHTZENHAIN, L. J.; BARBARINI, O.; UMEHARA, O.; DE GRACIA, A. S.; CORTEZ, A.; HEINEMANN, M. B.; FERREIRA, F.; SOARES, R. M. Diarréia Viral Bovina: levantamento sorológico nos estados de Minas Gerais, Mato Grosso do 
Sul, São Paulo, Rio de Janeiro, Paraná e Rio Grande do Sul. Arquivos do Instituto Biológico, São Paulo, v. 66, n. 1, p. 107-111, 1999.

RIDPATH, J. F. BVDV genotypes and biotypes: practical implications for diagnosis and control. Biologicals, London, v. 31, n. 2, p. 127-131, Jun. 2003.

RIDPATH, J. F. Practical significance of heterogeneity among BVDV strains: impact of biotype and genotype on U.S. control programs. Preventive Veterinary Medicine, Netherlands, v. 72, n. 1-2, p. 17-30, Nov. 2005.

RIDPATH, J. F.; BOLIN, S. R.; DUBOVI, E. J. Segregation of bovine viral diarrhea virus into genotypes. Virology, United States, v. 205, p. 66-74, Nov. 1994.

RIDPATH, J. F.; NEILL, J. D.; FREY, M.; LANDGRAF, J. G. Phylogenetic, antigenic and clinical characterization of type 2 BVDV from North America. Veterinary Microbiology, Netherlands, v.77, p. 145-155, Nov, 2000.

RIDPATH, J. F.; NEILL, J. D.; PETERHANS, E. Impact of variation in acute virulence of BVDV1 strains on design of better vaccine efficacy challenge models. Vaccine, Netherlands, v. 25, p. 8058-8066, Nov. 2007.

ROBSON, D. S.; GILLESPIE, J. H.; BAKER, J. A. The neutralization test as an indicator of immunity to virus diarrhea. The Cornell Veterinarian, United States v. 50, p. 503-509, Oct. 1960.

ROEDER, P. L.; HARKNESS, J. W. BVD virus infection: prospects for control. The Veterinary Record, England, v. 118, p. 143-147, Feb. 1986.

ROEHE, P. M.; OLIVEIRA, E. A. S.; OLIVEIRA, L. G.; MUNOZ, J. C. P. A situação do vírus da diarréia viral bovina no país. In: SIMPÓSIO INTERNACIONAL SOBRE HERPESVIRUS BOVINO (TIPO 1 E 5) E VÍRUS DA DIARRÉIA VIRAL BOVINA (BVDV), 1998, Santa Maria. Anais... Santa Maria, Rio Grande do Sul, 1998. p. 3948.

SAMARA, S. I.; DIAS, F. C.; MOREIRA, S. P. G. Ocorrência da diarréia viral bovina nas regiões sul do Estado de Minas Gerais e nordeste do Estado de São Paulo.

Brazilian Journal of Veterinary Research and Animal Science, São Paulo, v.41, p. 396-403, Set. 2004.

SANDVIK, T. Laboratory diagnostic investigations for bovine viral diarrhea virus infections in cattle. Veterinary Microbiology, Netherlands, v. 64, p.123-124, Jan. 1999. 
SANDVIK, T. Selection and use of laboratory diagnostic assays in BVD control programmes. Preventive Veterinary Medicine, Netherlands, v. 72, p. 3-16, Nov. 2005.

SAUSKER, E. A.; DYET, N. M. Seroprevalence of OHV-2, BVDV, BHV-1 and BRSV in ranch-raised bison (Bison bison). Journal of veterinary diagnostic investigation, United States, v. 14, n. 1, p. 68-70, Jan. 2002.

SCHIRRMEIER, H.; STREBELOW, G.; DEPNER, K.; HOFFMANN, B.; BEER, M. Genetic and antigenic characterization of an atypical pestivirus isolate, a putative member of a novel pestivirus species. The Journal of General Virology, England, v. 85, p. 3647-3652, Dec. 2004.

SCHWEIZER, M.; PETERHANS, E. Noncytopathic Bovine Viral Diarrhea Virus Inhibits Double-Stranded. Journal of Virology, United States, v. 75, n. 10, p. 46924698, May 2001.

TAJIMA, M.; DUBOVI, E. J. Genetic and clinical analyses of bovine viral diarrhea virus isolates from dairy operations in the United States of America. Journal of Veterinary Diagnostic Investigation, United States, v. 17, p. 10-15, Jan. 2005.

TAYLOR, L. F.; VAN DONKERSGOED, J.; DUBOVI, E. J. ; HARLAND, R. J. ; VAN DEN HURK, J. V.; RIBBLE, C. S.; JANZEN, E. D. The Prevalence of Bovine Viral Diarrhea Virus Infection in a Population of Feedlot Calves in Western Canada.

Canadian journal of Veterinary Research, Canada, v. 59, p. 87-93, Apr. 1995.

THRUSFIELD, M. Epidemiologia veterinária, 2. ed. São Paulo:, Roca, 2004. p. 340-42.

TREMBLAY, R. Transmission of bovine viral diarrhea virus. Veterinary Medicine, United States, v. 91, n. 9, p. 858-866, Sep 1996.

VAN OIRSCHOT, J. T.; BRUSCHKE, C. J.; VAN RIJN, P. A. Vaccination of cattle against bovine viral diarrhoea. Veterinary Microbiology, Netherlands v. 64, n. 2-3, p. 169-183, Jan. 1999.

VAN RIJN, P. A.; VAN GENNIP, H. G.; LEENDERTSE, C. H.; BRUSCHKE, C. J.; PATON, D. J.; MOORMANN, R. J.; VAN OIRSCHOT, J. T. Subdivision of the pestivirus genus based on envelope glycoprotein E2. Virology, United States, v. 27, n. 237, p. 337-348, Oct. 1997 
VIDOR, T. Isolamento e identificação do vírus da doença das mucosas no Rio Grande do Sul. Boletim Instituto Pesquisas Desidério Finamor, Porto Alegre, v. 5, p. 51-58, 1974.

VILCEK, S.; DURKOVIC, B.; KOLESAROVA, M.; GREISER-WILKE, I.; PATON, D. Genetic diversity of international bovine viral diarrhoea virus (BVDV) isolates: identification of a new BVDV-1 genetic group. Veterinary Research, France, v. 3, p. 609-615, Sep/Oct. 2004.

VILCEK, S.; PATON, D. J.; DURKOVIC, B.; STROJNY, L.; IBATA, G.; MOUSSA, A.; LOITSCH, A.; ROSSMANITH, W.; VEJA, S.; SCICLUNA, M. T.; PAIF, V. Bovine viral diarrhea virus genotype 1 can be separated into at least eleven genetic groups. Archives of Virology, Austria, v. 146, n. 1, p. 99-115, 2001.

VILELA, C. O.; QUINCOZES, C. G.; GOMES, F. R.; FISCHER, G.; BARUEL, C. C.; FERREIRA, L. N.; OLIVEIRA, L. S.; VIDOR, T. Prevalência de BVD em rebanhos com problemas reprodutivos no sul do Rio Grande do Sul. In: CONGRESSO DE INICIAÇÃO CIENTÍFICA, 12.; Encontro da Pós-Graduação, 5., 2003, Pelotas.

Anais... 2003. p. .

VOGEL, F. S. F.; FLORES, E. F.; WEIBLEN, R.; MAYER, S. V.; QUADROS, V. L.; OLDONI, I. Magnitude, duração e especificidade da resposta sorológica em bovinos vacinados contra o vírus da diarréia viral bovina (BVDV). Ciência Rural, Santa Maria, v. 32 n. 1, p. 83-89, Fev. 2002

WITTUM, T. E.; GROTELUESCHEN, D. M.; BROCK, K. V.; KVASNICKA, W. G.; FLOYD, J. G.; KELLING, C. L.; ODDE, K. G. Persistent bovine viral diarrhoea virus infection in US beef herds. Preventive Veterinary Medicine, Netherlands, v. 13, n. 49, p. 83-94, Apr. 2001.

WIZIGMANN, G.; VIDOR, T.; RICCI, Z. M. T. Investigações sorológicas sobre a ocorrência e incidência dos vírus PI-3, IBR e diarréia a vírus enfermidade das mucosas no Estado do Rio Grande do Sul. Boletim Instituto Pesquisas Desidério Finamor, Porto Alegre, v. 1, p. 52-58, 1971.

WOODARD, L. F. BVD virus associated with outbreaks of abortion, stillbirths, and weak calves. Veterinary Medicine, United States, v. 89, n. 4, p. 379-384, Apr. 1994.

ZUPANCIC, A.; JUKIC, B.; LOJKIC, M.; CAC, Z.; JEMERSIC, L.; STARESINA, V. Prevalence of antibodies to classical swine fever, Aujeszky's disease, porcine reproductive and respiratory syndrome, and bovine viral diarrhoea viruses in wild 
boars in Croatia. Journal of Veterinary Medicine. B, Infectious Diseases and Veterinary Public Health, Germany, v. 49, n. 5, p. 253-256, Jun. 2002. 